\title{
DOCUMENTALES Y DOCUMENTALISTAS ANTIOQUEÑOS. Sentido y práctica de un oficio que narra una región
}

\author{
Mónica Valle* \\ Santiago Gómez Sánchez** \\ José Miguel Restrepo*** \\ Juan Andrés Gómez**** \\ Wilmar Raigosa***** \\ DOI: https://doi.org/10.33571/revistaluciernaga.v11n21a1
}

\section{Resumen}

Para el crítico de cine Luis Alberto Álvarez "Las únicas razones verdaderas para la existencia del [Cine] documental colombiano son dos: crear el espejo de nuestra propia identidad y la posibilidad de expresión artística, personal y socialmente significativa. En este artículo se presenta algunos de los resultados de la investigación Documentales y Documentalista Antioqueños la cual tuvo entre sus objetivos analizar la estructura narrativa y propuesta estética en la obra de los documentalistas Carlos Bernal, Oscar Mario Estrada y José Miguel Restrepo Moreno. Específicamente en este texto solo se expone los hallazgos referentes a las temáticas y escenarios así como la metodología utilizada en el estudio.

El tema de los niños es recurrente en estos documentalistas así como sus cosmovisiones de ciudad y ruralidad. El universo narrativo de Bernal incluye, además las faenas de los oficios. Las atmósferas y personajes de Oscar Mario Estrada, narran, crean y recrean el sentido de la expresión humana popular que generalmente pasa desapercibida en la vida cotidiana. La narrativa experimental y desconstructiva de José Miguel Restrepo, visibiliza un mundo arremolinado por tiempos, personajes, lugares, historias y animales que cruza en la edición para colocar en primer plano la experiencia de vida marginal. La alusión al fútbol como entretenimiento, práctica y su fanaticada, también está presente en la obra de estos documentalistas así como el juego de ajedrez, los medios de comunicación y la música. El mosaico de narrativas, historias e imágenes capta una forma de ser, estar y habitar la región antioqueña.

Palabras clave: documental; video; audiovisual; cine, narrativas; Carlos Bernal; Oscar Mario Estrada; José Miguel Restrepo Moreno; investigación audiovisual; tratamiento audiovisual; estética; Antioquia.

Recibido. Enero 23, $2019 \quad$ Aceptado. Febrero 28, 2019

*Doctora en Estudios Científicos y Sociales- Universidad Jesuita de Guadalajara-México-Iteso. Magister en Comunicación- Universidad Iberoamericana de México-Plantel Santa Fe- UIA. Especialista en Gerencia de la Comunicación- Universidad Pontificia Bolivariana Medellín- UPB. Comunicadora Social-Periodista- Universidad de Antioquia- Colombia. Docente e investigadora del Politécnico Colombiano Jaime Isaza Cadavid. En la investigación participó en la construcción de la metodología, análisis e interpretación de datos y redacción del artículo. Orcid: https://orcid.org/0000-0003-1803-1115; e-mail: mmvalle@elpoli.edu.co 
**Magíster en Literatura y candidato a Doctor en Literatura de la Universidad de Antioquia. Docente en el Área de Lingüística y Literatura de la Universidad de Antioquia. En la investigación realizó el análisis crítico de cada uno de los documentales estudiados; e-mail: omagicoaudiovisual@gmail.com

***Profesor Asociado de la Facultad de Comunicación Audiovisual del Politécnico Colombiano Jaime Isaza Cadavid. Magister en Educación y Desarrollo Humano; Comunicador Social de la Universidad Pontifica Bolivariana. En la investigación participó como investigador principal, aportó a la construcción del proyecto, la metodología, administración y coordinación de personal y recurso financiero, sistematización de datos, análisis e interpretación de datos. Orcid. https://orcid.org/0000-0002-3966-8505; e-mail: jmrestrepo@elpoli.edu.co

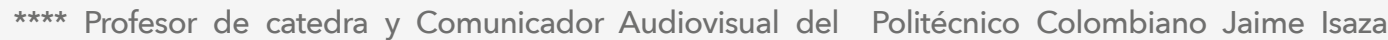
Cadavid. En la investigación fue Co-investigador. Realizó sistematización de datos, análisis e interpretación de datos y análisis crítico; e-mail: juan_gomez20103@elpoli.edu.co; juanandresgomezg@gmail.com

${ }^{\star \star \star *}$ Comunicador Audiovisual- Politécnico Colombiano Jaime Isaza Cadavid. En la investigación participo como co-investigador. Realizó sistematización de datos; email: wilmar_120@hotmail.com

\title{
DOCUMENTARIES AND DOCUMENTALISTS FROM ANTIOQUIA. Meaning and practice of a job that narrates a region
}

\author{
Mónica Valle* \\ Santiago Gómez Sánchez** \\ José Miguel Restrepo*** \\ Juan Andrés Gómez**** \\ Wilmar Raigosa***** \\ DOI. https://doi.org/10.33571/revistaluciernaga.v11n21a1
}

\section{Summary}

According to the film critic Luis Alberto Álvarez, "The only real purpose for the existence of the Colombian documentary [Cine] are two: to create the mirror of our own identity and the possibility of artistic, personal and socially significant expression. This article presents some of the results of the research documentaries and documentary filmmaker Antioqueños, which aimed to analyze the narrative structure and aesthetic proposal in the work of the antioqueños documentary filmmakers Carlos Bernal, Oscar Mario Estrada and José Miguel Restrepo Moreno. Specifically, this text only exposes the findings related to the topics and scenarios as well as the methodology used in the study.

It is found that children topic is recurrent in these documentalists, as well as their cosmovision of city and rurality. Bernal's narrative universe also includes the deals of trades and music. Oscar Mario Estrada's atmospheres and characters narrate, create and recreate the sense of popular human expression that generally goes unnoticed in everyday life. The experimental and deconstructive narrative by José Miguel Restrepo reveals a turbulent world due to time, characters, places, stories, and animals that he involves in the edition, placing in the foreground the vital experience of marginality. In the production of these documentary filmmakers, fragments of culture are caught; and territories are observed, heard, felt, perceived and lived. 
Keywords: documentary; video; audiovisual; cinema; narrative; Carlos Bernal; Oscar Mario Estrada; José Miguel Restrepo Moreno; audiovisual research; audiovisual treatment; aesthetics; Antioquia.

Received. January 23, 2019

Accepted. February 28, 2019

\title{
DOCUMENTÁRIOS E DOCUMENTALISTAS ANTIOQUIANOS. Sentido e prática de uma ocupação que narra uma região
}

\author{
Mónica Valle* \\ Santiago Gómez Sánchez** \\ José Miguel Restrepo*** \\ Juan Andrés Gómez $z^{\star \star * *}$ \\ Wilmar Raigosa ***** \\ DOI. https://doi.org/10.33571/revistaluciernaga.v11n21a1
}

\section{Summary}

Para o crítico de cinema Luis Alberto Álvarez, "As únicas razões reais para a existência do documentário colombiano [Cine] são duas: criar o espelho de nossa própria identidade e a possibilidade de expressão artística, pessoal e socialmente significativa. Este artigo apresenta alguns dos resultados da pesquisa documental e documentarista Antioqueños que teve entre seus objetivos analisar a estrutura narrativa e a proposta estética do trabalho dos realizadores de documentários Antioqueños Carlos Bernal, Oscar Mario Estrada e José Miguel Restrepo Moreno. Especificamente, este texto expõe apenas os achados relacionados aos temas e cenários, bem como a metodologia utilizada no estudo.

Constata-se que o tema das crianças é recorrente nesses documentalistas, bem como em suas cosmovisões de cidade e ruralidade. $O$ universo narrativo de Bernal também inclui as tarefas dos ofícios e da música. Os ambientes e personagens de Oscar Mario Estrada narram, criam e recriam o sentido de expressão humana popular que geralmente passa despercebido no cotidiano. A narrativa experimental e desconstrutiva de José Miguel Restrepo torna visível um mundo agitado por tempos, personagens, lugares, histórias e animais que cruza na edição para colocar em primeiro plano a experiência vital da marginalidade. Na produção desses cineastas documentários, fragmentos de cultura, território, contemplados, escutados, sentidos, percebidos e vividos são capturados.

Palavras-chave: documentário; vídeo; audiovisual; cinema; narrativa; Carlos Bernal; Oscar Mario Estrada; José Miguel Restrepo Moreno; pesquisa audiovisual; tratamento audiovisual; estética; Antioquia.

Recebido. Janeiro 23, 2019

Aceito. Fevereiro 28, 2019 


\section{Introducción}

La Facultad de Comunicación Audiovisual del Politécnico Colombiano Jaime Isaza Cadavid con la finalidad de desarrollar y estimular la investigación, la reflexión y las publicaciones sobre el sector audiovisual aprobó mediante convocatoria interna la realización de esta investigación en tanto se requiere dimensionar el campo investigativo de esta área de estudio y campo profesional en el país, determinar las transformaciones y mutaciones en las maneras de narrar o contar historias en diversos contextos mediáticos y tecnológicos, así como el diálogo a nivel regional, nacional e internacional con la comunidad académica involucrada en dicho campo. Entre las problemáticas que se encuentran en este sector es la falta de financiación para la producción documental, una pobre actualización en la docencia y el aprendizaje en el área, la falta de conocimiento del tipo de producciones a las que se abocan los realizadores y productores en el país, faltan inventarios y archivos audiovisuales de la producción y sus autores.

En tal sentido con este proyecto se pretendió aportar al acervo de conocimiento específicamente en torno a la sistematización, reconocimiento y análisis de los documentalistas y sus obras de la región antioqueña. Labor de largo aliento, que por lo pronto aborda el análisis de la obra de los documentalistas antioqueños Carlos Bernal, Oscar Mario Estrada y José Miguel Restrepo Moreno. Específicamente en este texto solo se exponen los hallazgos referentes al sentido y la práctica de un oficio en la que se narra una región. Sin embargo es de anotar que lo relacionado al análisis de la estructura dramática y narrativa, la contextualización de los sucesos socio-históricos registrados en los documentales, personajes y demás temáticas, estará incluida en otros artículos y los libros, producto de esta investigación.

En relación con el audiovisual en Antioquia señala Gómez (2017).

"En el audiovisual paisa, desde sus pioneros cinematográficos (Gonzalo Mejía[1], Camilo Correa[2], Enoc Roldán[3]), la imagen, los mismos esquemas de producción, y aún las motivaciones, siempre fueron como unos ojos de infante que se dejaran empapar por el clima neblinoso de las montañas, por la acogedora humareda y luciferinas pavesas de nuestras fogatas, por el adormecedor zureo de nuestras comadres en el pasillo vespertino, y sobre todo por la locura mística, por el alucinante empeño de nuestros próceres anónimos, como la Madre Laura en Luz en la selva (1960), de Roldán, o como lo era el propio Camilo Correa armando procesiones callejeras en honor al cine de las criadas y los celadores. Cine místico hecho por místicos, o cuando menos cine folclorista y muy celoso de su ancestro cultural, como en los casos de Gonzalo Mejía (Bajo el cielo antioqueño -1925) y el propio Correa (Colombia Linda -1955), en el crepúsculo de los setenta y los albores de los ochenta el cine antioqueño tuvo su momento cumbre en las figuras de Juan Escobar y Regina Pérez[4], Gonzalo Mejía (el otro)[5] y Víctor Gaviria. Películas como Será por el silencio (1983, Juan Escobar y Regina Pérez), Hulleras (1980, Gonzalo Mejía) o Buscando tréboles (1978, Víctor Gaviria) consiguieron encarnar unas formas de vida soberanamente singulares, riquísimas en significado, con una nitidez que, para quien las contemplaba, le hacía correr el peligro de que sólo percibiera en ellas su sabor local -la misma recepción que, por otra parte, tuviera en Colombia la obra de Carrasquilla". Blog Madera Salvaje 


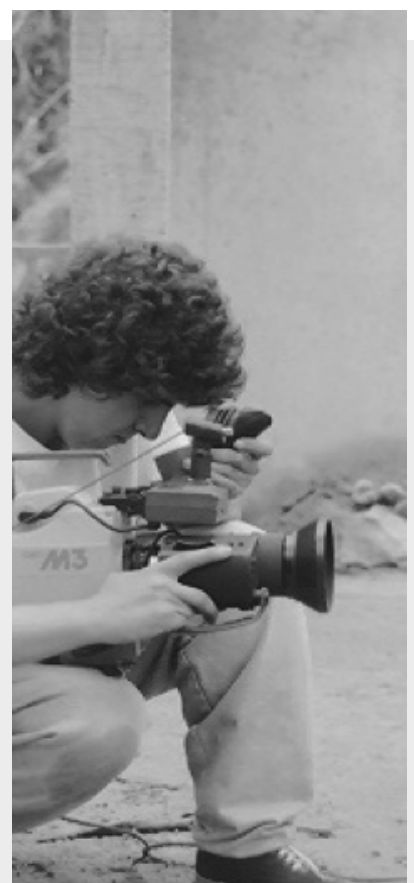

Carlos Mario Bernal

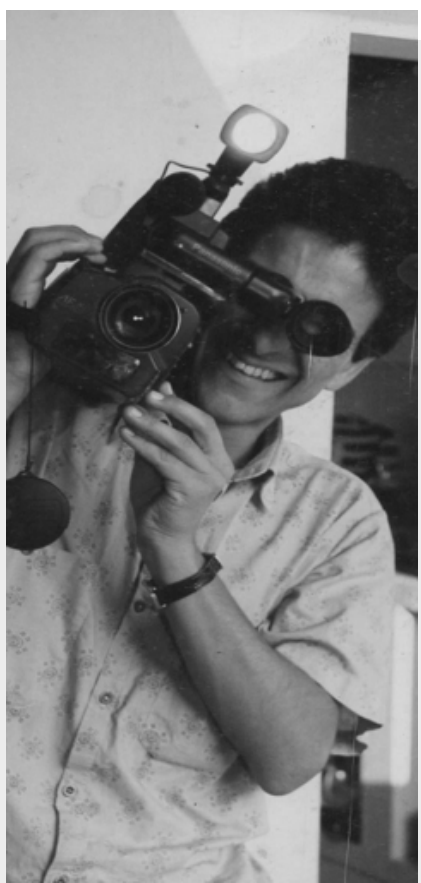

Oscar Mario Estrada

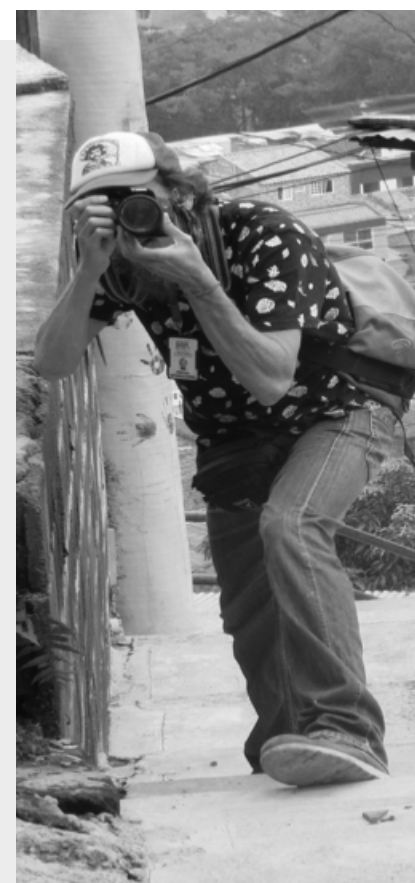

José Miguel Restrepo

Las obras analizadas en este estudio se ubican entre 1986 y 2012, en éstas se visibilizan el tema de los niños así como las cosmovisiones de ciudad, el barrio y la ruralidad. Para Bernal, hay una interdependencia entre la ciudad y el campo, la provisión alimenticia es de vital importancia y en esta, los cultivos orgánicos son una opción. La contaminación ambiental de la ciudad es una temática que Bernal avizoraba en el 2004, y que a esta fecha (2019), se constituye en uno de las problemáticas más graves de Medellín. La ciudad y el campo de Bernal sigue su tránsito hacia realidades más caóticas, pero no por ello deja de ser bella y entrañable, en ella los colores primaverales se interrumpen por la violencia, el concreto y el hierro. En esta cotidianidad los medios de comunicación están inmersos. En la obra de Estrada, la nostalgia por la vida del Pueblo es evidente: los lugares que tienen vida social como las tiendas en las que se canta, se hace poesía, se toca música, se conversa, se dejan y reciben recados, son los lugares que perpetúa este documentalista. Estos espacios ya son la excepción en los municipios de la región que paso a paso se convierten en urbes.

En la ciudad habitada, percibida, narrada, documentada por Restrepo, hay "paramilitares", comunas, mafias, falta educación, los medios de comunicación "vende" basura. Pablo Escobar sigue siendo un héroe en las comunas y un referente de ciudad para los extranjeros. En el barrio, los cristianos, tienen sus más fieles discípulos y la vida parece un mal trance. La ruralidad que registra Restrepo al igual que en la ciudad y el barrio, están vitalmente cohesionado por el drama, la tragedia, la comedia, el melodrama y hasta por el cinismo. Los campesinos, no tienen donde vender sus productos, pero tienen teléfono celular. Ese espacio vital del campesino está siendo penetrado por la modernidad y los nuevos proyectos al servicio del turismo. Ellos siguen apegados al Sagrado Corazón de Jesús, mientras en las veredas todavía se sacrifica al "marrano" para festejar la fiesta de navidad, aunque el discurso civilizatorio se refiera al no maltrato animal. 
También está presente en la obra de estos documentalistas la alusión a la violencia, lugares y no lugares, el fútbol como entretenimiento, práctica y su fanaticada; así como las diferentes formas de entretenimiento tales como el festival, los medios de comunicación y el juego de ajedrez. El mosaico de narrativas, historias e imágenes capta una forma de ser, estar y habitar la región antioqueña.

\section{Metodología}

La metodología de este proyecto fue de corte estructuralista y cualitativo; el proceso se concibió en 6 momentos: 1. Determinación del corpus de análisis (10 documentales seleccionados al azar, por cada Director). 2. Construcción de categorías, subcategorías e indicadores con fundamento en la propuesta conceptual de Casseti y Di Chio (1991) y el equipo investigador. 3. Diseño de matrices para el análisis. 4. Sistematización de datos en las matrices. 5. realización de entrevistas semi-estructurada a cada documentalista. 6. Se realizó crítica de cada uno de los documentales la cual se interpretó a la luz de los datos recogidos en las plantillas. Uno de los documentalistas estudiados, se incorporó a la investigación lográndose mayor reflexividad en el proceso. A continuación algunas de las plantillas estructuradas.

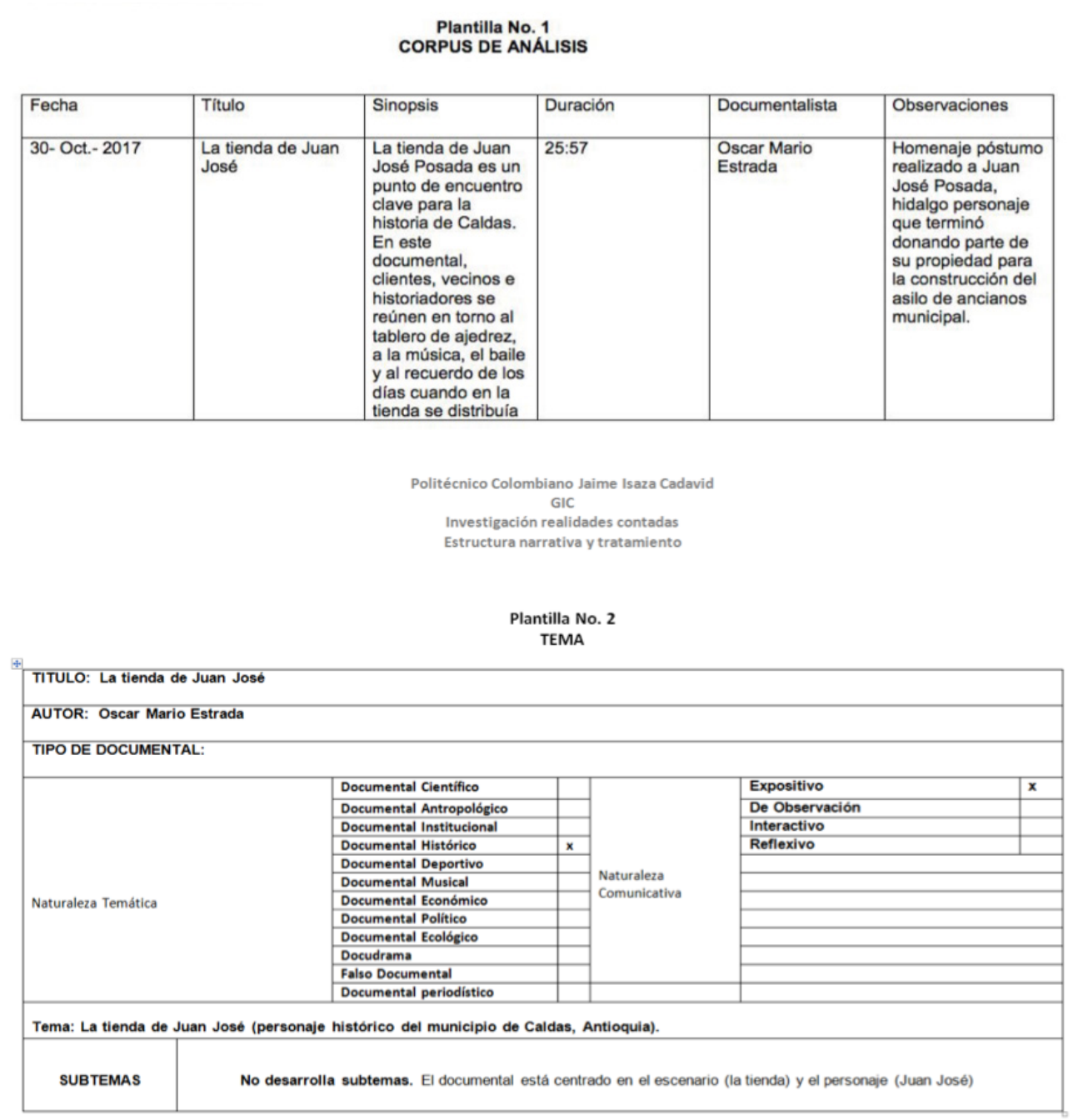


Investigación realidades contadas

Estructura narrativa y tratamiento

Plantilla No. 3

DESARROLLO DE LA NARRACIÓN EN LA LÍNEA DE TIEMPO (Estructura dramática)

\begin{tabular}{|c|c|c|c|c|c|}
\hline \multicolumn{2}{|r|}{ Inicio } & \multicolumn{2}{|c|}{ Desarrollo / Nudo/ Transformación } & \multicolumn{2}{|c|}{ Fin / Desenlace /Meta } \\
\hline Duración & Descripción & Duración & Descripción & Duración & Descripción \\
\hline $00: 00-01: 08$ & Conteo regresivo & $01: 09-24: 05$ & $\begin{array}{l}\text { Testimonios de los habitantes de Caldas } \\
\text { sobre Juan José Posada. }\end{array}$ & & Créditos finales \\
\hline & $\begin{array}{l}\text { Estación con un tren a blanco y } \\
\text { negro }\end{array}$ & & Imágenes antiguas de Caldas & & $\begin{array}{l}\text { Logo de Cala Televisión y } \\
\text { Nickel producciones }\end{array}$ \\
\hline & $\begin{array}{l}\text { Partituras y músico tocando un } \\
\text { piano }\end{array}$ & & $\begin{array}{l}\text { Testimonio de Rodrigo Morales sobre la } \\
\text { historia de la tienda de Juan José }\end{array}$ & & Fundido a negro. \\
\hline & $\begin{array}{l}\text { Partición de pantalla con } \\
\text { jntectitula. Blanco y negro. } \\
\text { Texto: } \\
\text {-Existen momentos } \\
\text { inolvidables.. } \\
\text {-Cosas inexplicables... } \\
\text {-Y personas incomparables... }\end{array}$ & & $\begin{array}{l}\text { Imágenes antiguas del ferrocarril de } \\
\text { Amagá }\end{array}$ & & \\
\hline & $\begin{array}{l}\text { Cámara lenta con escorzo de } \\
\text { caballo }\end{array}$ & & $\begin{array}{l}\text { Testimonio de Luis Alberto Zapata } \\
\text { "Chabeto" sobre el ferrocarril }\end{array}$ & & \\
\hline & Crédito Nikel producciones & & $\begin{array}{l}\text { Imágenes en blanco y negro de tren en } \\
\text { movimiento }\end{array}$ & & \\
\hline
\end{tabular}

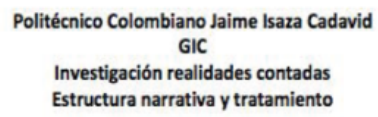

\begin{tabular}{|c|c|c|c|c|c|c|c|c|}
\hline Nombre & $\begin{array}{c}\text { Princip } \\
\text { al }\end{array}$ & $\begin{array}{c}\text { Secundari } \\
\text { os }\end{array}$ & $\begin{array}{l}\text { Figurant } \\
\text { es }\end{array}$ & $\begin{array}{l}\text { Contextu } \\
\text { ra física }\end{array}$ & Vestuario & $\begin{array}{l}\text { Señales } \\
\text { particulare } \\
\text { s }\end{array}$ & $\begin{array}{l}\text { Color } \\
\text { de piel }\end{array}$ & \\
\hline $\begin{array}{l}\text { a. Juan } \\
\text { Bautista } \\
\text { Usma } \\
\text { Vanegas }\end{array}$ & & $\mathrm{x}$ & & Delgado. & $\begin{array}{l}\text { Sombrer } \\
\text { o, camisa } \\
\text { a } \\
\text { cuadros, } \\
\text { corbata } \\
\text { roja, } \\
\text { chaleco } \\
\text { negro y } \\
\text { saco gris. }\end{array}$ & Anciano & Morena & Expresivos y enfáticos. \\
\hline $\begin{array}{l}\text { b. Rodrigo } \\
\text { Morales }\end{array}$ & & $x$ & & Delgado. & $\begin{array}{l}\text { Camisa } \\
\text { clara, } \\
\text { mangas } \\
\text { largas } \\
\text { recogida } \\
\text { sy } \\
\text { pantalón } \\
\text { gris. }\end{array}$ & & $\begin{array}{l}\text { Trigueñ } \\
\text { a. }\end{array}$ & Expositivos. \\
\hline $\begin{array}{l}\text { c. Luis } \\
\text { Albert } \\
\text { Zapata }\end{array}$ & & $x$ & & Delgado. & $\begin{array}{l}\text { Gorra, } \\
\text { gafas, }\end{array}$ & & $\begin{array}{l}\text { Trigueñ } \\
\text { a. }\end{array}$ & Tranquilos. \\
\hline
\end{tabular}




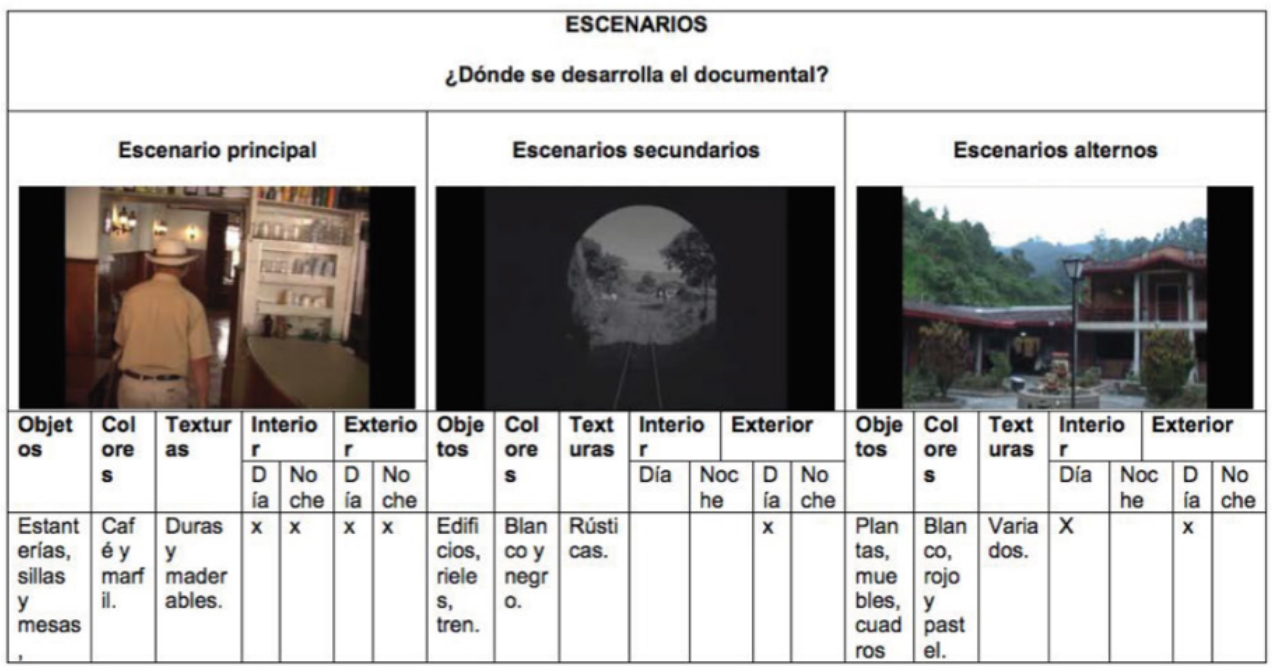

\section{Imágenes de entrevistas realizadas a los documentalistas}

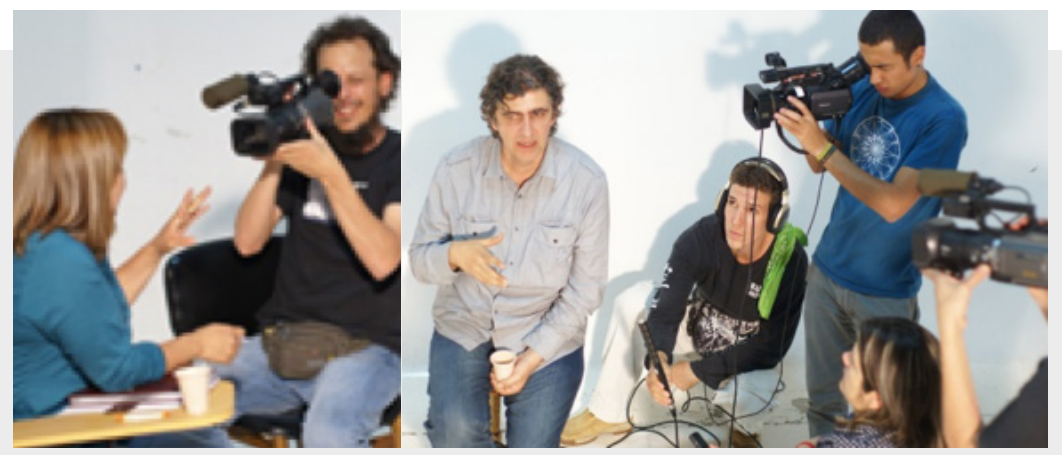

José Miguel Restrepo

Carlos Bernal Acevedo

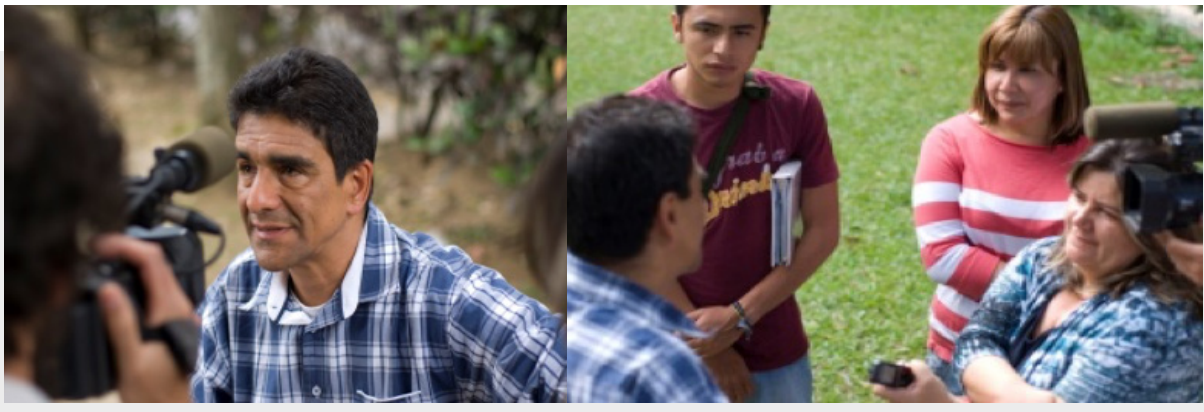

Entrevista a Oscar Mario Estrada 


\section{Los Documentalistas}

Los documentalistas Carlos Bernal [6], Oscar Mario Estrada Velázquez [7], José Miguel Restrepo [8], se desempeñan como profesores en reconocidas Universidades de Colombia [9], los tres son oriundos de la región antioqueña, sus títulos de pregrado son en comunicación, y se han desempeñado en el campo audiovisual como productores, realizadores y directores. Bernal y Estrada se titularon en la Universidad de Antioquia y Restrepo en la Universidad Pontificia Bolivariana. En el corpus de análisis de esta investigación se registra a "Son del Barro" (1986) como uno de los primeros documentales de Bernal, su producción en general se ubica entre finales de los años 80 y los 90. La obra de Estrada, considerada en este estudio, se ubica entre el año 2003 y 2012; y la de José Miguel Restrepo (Joche) desde el 2004 al 2012. Si se toma como referencia la fecha de culminación de sus estudios de pregrado y la edad de los documentalistas, se podría considerar a Bernal como el primero de este trio, seguido por Estrada y Restrepo.
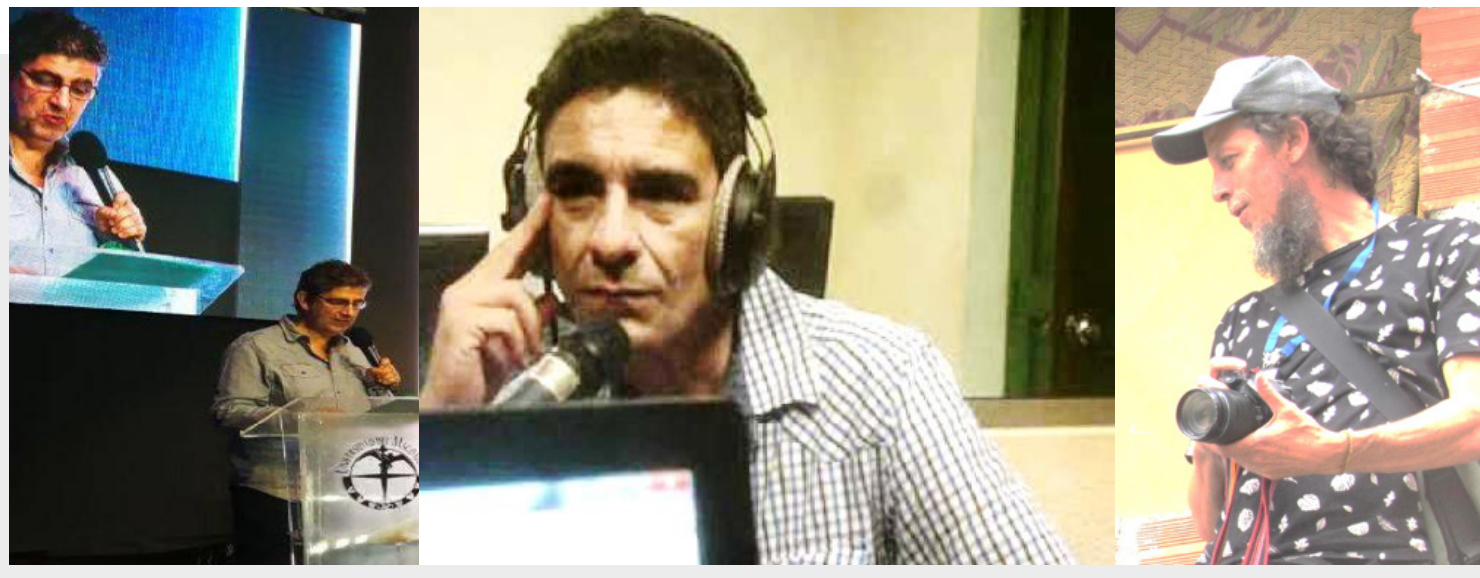

\subsection{El inicio}

Son diversas las motivaciones que llevaron a los documentalistas a optar por ese arte y consolidarse en éste, siendo las más contundente el interés por contar historias, su necesidad de expresarse, su formación en comunicación, los contexto o ambientes audiovisuales y culturales a los que estuvieron expuestos, la conformación de colectivos para producir así como las experiencias académicas a nivel internacional, el reconocimiento de otros y el auto-reconocimiento de ciertas habilidades para la creación documental.

\subsubsection{Narrar Historias}

Las historias llevan al documental. Carlos Bernal, llega al documental mucho después de su interés por el diseño gráfico y la publicidad, ya que desde los 15 años se dedicaba a estas labores. Inicia estudios en la Universidad de Antioquia los cuales suspende, por un tiempo, para irse a España a estudiar televisión. Regresa a Colombia a finales de 1980, por la época en que se estaba en el montaje de Teleantioquia [10]. 
[Bernal] "Yo llegué al documental no en el sentido de habérmelo propuesto, como la idea de voy a ser documentalista, porque inclusive yo diría que en esa época del 86 que se hizo "Son del Barro" para mí no era tan clara la palabra, ni siquiera el concepto de documental, era un ejercicio un poco más experimental... Yo pienso que son las historias la que te llevan a hacer documentales, películas, no es voy a hacer un documental entonces busquemos la historia... lo que era interesante en "Son del Barro" (1896) era como unos trabajadores, unos obreros en un proceso muy largo habían terminado administrando, produciendo y manejando una fábrica, y era el interés por esa historia la que llevó a la cámara, además una ladrillera es un fenómeno que para cualquier fotógrafo es un delirio, eran 25 mil ladrillos en un horno, eso visualmente es monumental para un fotógrafo, y yo soy fotógrafo".

En sus inicios este documentalista trabajo en Tiempos Modernos, fundada por el cineasta Víctor Gaviria [11] a mediados de los años 80 [12].

Narrar y recrear historias que permitan soñar. El mirar la "odisea del espacio" esa en la que el mundo se quedó paralizado con la transmisión en directo de la llegada del hombre a la luna, fue la primera aproximación que Oscar Mario Estrada [13] tuvo con la magia de la imagen y su capacidad de asombro. Esto lo vivió en el sencillo hotel, Fredonia, que regentaba su abuela Otilia Ramírez. Fredonia significa tierra de libertad, dice Estrada.

[Estrada]..."Justo, el día del alunizaje, en un gesto visionario, mi abuela compró un televisor en blanco y negro, para presenciar "un primer paso para el hombre, un gran salto para la humanidad". Esa noche, los pueblerinos de nuestra localidad, ocuparon la nave central del hotel.... Años después en el municipio de Jericó, de la escuela nos llevaban al teatro Santamaría a ver películas inspiradas en los textos de la biblia: "Los diez mandamientos", "Sansón y Dalila", luego por vocación propia, yo vi las películas de karate, con Bruce Lee a bordo y posteriormente con mis compañeros de colegio, la saga de las colegialas. Las cuales nos enseñaron, no solo a soñar, sino a desvelarnos, con estas estrellas del "filmamento"... Una vez en Medellín, leía las crónicas del "cura litro", el sacerdote de avanzada Luis Alberto Álvarez, quien me dio las rutas de navegación para entender el cine, en seminarios especiales, que tenían una fuerza adictiva y una pasión infinita. Pero mis primeros pinos en la realización, fueron con mi amigo Humberto Suárez, cuya familia tenía una empresa de distribución de videos y allí ingresé a la BBC (Bodas, Bautizos y Primeras Comuniones), experiencia fabulosa, en la cual, los camarógrafos éramos "los héroes de la ocasión" y nos brindaban los mejores platos a la hora de la cena".

Historias de viaje, de vida...La necesidad de "husmear" la vida lleva a José Miguel Restrepo al documental.

[Joche] "Yo andaba mucho, me ha gustado viajar, eso me ha abierto muchas puertas y he podido husmear bastante. Ese interés lo he tenido siempre, incluso mucho antes de hacer documental. En ese tiempo no existía la palabra mochilero pero yo era un mochilero; me encantaba irme a dedo para todo lado, dejaba la universidad, dejaba el colegio y me largaba y me iba a vivir a otros lugares...Si yo mañana me voy para el Amazonas, extraño sería que no llevara mis equipos y estando allá sin querer hacer un documental, se me aparece cualquier historia y la 
desarrollo... es como un diario; un diario no sé si de viaje. Creo que la vida es un viaje, porque a veces cuando estoy metido en la ciudad, también estoy viajando, conociendo gente, historias, situaciones. Después de 40 años yo sigo metiéndome a espacios y a lugares que nunca me imaginaba que existieran; entonces, mis documentales son como una bitácora de vuelo, de vida, de espacios, de gente y eso se va convirtiendo en un gran álbum. Alguien alguna vez en el Ministerio de Cultura, cuando estaba presentando un pitch [14] de un documental, me dijo de manera despectiva "es que esto sigue siendo lo mismo tuyo, una historia de tu vida" y sí, creo puede ser una especie de historia de mi vida y las personas que van cruzando en torno a ella".

En las primeras grabaciones de Restrepo que datan de comienzos de la década del 1990, se observa sus viajes en camión, caminatas por calles solitarias al lado de mendigos, su odisea a la ciudad de Santiago de Cali en bus de TSS a ver jugar al Independiente Medellín un partido con el América de Cali. Joche mantiene la filosofía de extimidad para instruir a su público, llevándonos a conmoción, como es el caso del fin del viaje al Amazonas, cuyas alabanzas cristianas que se escuchan en mitad de uno de sus documentales llevan a la gente a sentir compasión y arrepentimiento en medio de alucinaciones padecidas por él como personaje, en rituales indios a través de sus búsquedas en territorio peruano [Gómez, 2013].

\subsection{Esos muchachos tienen madera}

Estos documentalistas se afianzaron en su labor por el reconocimiento y la valoración que de su trabajo hicieron reconocidos personajes de la cultura, el cine, también sus profesores así como por los premios obtenidos y las convocatorias en las que resultaron elegidos.

[Estrada] "En las aulas, del alma mater [U de A] hice mi primer trabajo audiovisual, una suerte de sonoviso, género, desaparecido del planeta, llamado: "Zapaticos de charol", un sencillo homenaje a la foto clásica y alucinante del maestro Melitón Rodríguez [15] y mi tratamiento consistió en hacer imágenes y sonidos con los zapateros populares de la ciudad. En ese momento a mi profesor Álvaro Ramírez Ospina, gran maestro, le gustó mi trabajo y dijo: Ese muchacho tiene madera".

Estrada también ha sido seleccionado para realizar pasantías en el exterior; con el Ministerio de Cultura de Colombia en alianza con el Fondo Nacional para la Cultura y las Artes -FONCA- de México, viajó a ese país y allí realizó el documental "México en el espejo del cine", el cual fue emitido por el Canal Iberoamericano de la UNAM, Señal Colombia y canales regionales.

[Bernal] [Cuando estaba haciendo el piloto de Son del Barro] no contaba con equipos profesionales, Ricardo Aricapa, personaje conocido dentro de la escena de la cultura en Antioquia, ve "Son del Barro" y dice "esto lo tiene que ver Víctor Gaviria [16] , me llevan allá, él lo ve, y dice: Nooo, esto es una nota, hazlo con nuestros equipos... en ese sentido a partir de esa historia interesante, y de ese tipo de filmación, y de esa experimentación con el lenguaje, es que me fui abriendo un camino..." . [Restrepo] "Yo empecé a participar en 
convocatorias y eso me abrió puertas de otras maneras de producir. Entonces muchos años viví de ganarme premios y de juntarme con gente que podía realizar". Continua Restrepo "Santiago Gómez otro de los fundadores de Manera Salvaje se ganó el Premio al mejor documental que entregaba el Ministerio de Cultura, con "Diario de viaje"(1996) que trata de cinco "pelaos" que van a un festival de cine, él tuvo el rigor de ponerse a editar, lo que no hicimos nosotros...de esa época de Madera quedó también un trabajo muy bueno, que lo hicimos con las milicias populares en la Comuna nororiental que se llamaba "A la rueda, rueda de paz y candela" (1995).

En marzo de 2019, en el Festival de Málaga (2019), el cortometraje documental El día de los conectados, en el que Restrepo fue uno de los directores, obtuvo el Premio del Público.

\subsection{Conformación de equipos de trabajo y colectivos para producir}

Aparece como una constante importante en la producción documental de los realizadores antioqueños, la conformación de equipos, colectivos de trabajo; integrados por pares, amigos y familiares. Esta figura parecer ser uno de las formas en que estos profesionales se apropiaron y desarrollaron capacidades para trabajar con otros en procura de un producto común, lograron competencias y habilidades para la vida y aprendizajes de su área profesional.

José Miguel Restrepo, es uno de los documentalistas que más colectivos ha conformado e integrado, entre 1992 y 93, empezó a realizar documentales con un grupo de compañeros del Programa de Comunicación Social de la Universidad Pontificia Bolivariana, para ello crearon el colectivo y corporación cultural Madera Salvaje. El colectivo se estableció con 21 integrantes y terminaron solo 7, lograron algunos recursos financieros; del Ministerio de Cultura obtuvieron algo de dinero para para producir el documental "Santificar las fiestas"

Este colectivo así como sus sueños se acabaron pronto. Dice Restrepo: el tiempo mostró que nosotros éramos desordenados y muy austeros en nuestra manera de producir, esto lo hacíamos porque estábamos tratando de ahorrar y generar fondos para montar una productora, entonces como el "billete" se fue, nosotros nos quedamos con unas cuantas cámaras, con la producción y la gente del Ministerio de Cultura dijo, arreglemos esto por las buenas, quédense con el material, nosotros nos largamos de este proyecto, no les damos más plata. Eran 60 millones en ese tiempo. Todo se acabó expresa Restrepo.

¿Por qué esas dificultades? [Joche] "...por los diferentes estilos de vida y de trabajo de los integrantes, también porque nos gustaba mucho la fiesta. En ese tiempo éramos muchachos muy viscerales. En medio de ese bullicio. Se grabaron muchas horas, puedo pensar en 500, 700 horas y casi todas se perdieron.

En este colectivo también hubo cosas positivas, se ganó en experiencia, allí Restrepo empezó a hacer cámara desde una perspectiva distinta a la 
formal, clásica. Dice Restrepo "nosotros queríamos una cámara documental muy natural, sin muchas intenciones, ni especificidad.

[Restrepo] por la precariedad que teníamos de equipos, yo me empecé a idear una manera de editar las historias en la misma cámara, en el mismo tiempo de grabación y que quedaran casi perfectas al momento de ser grabadas... Entonces yo jugaba mucho con el fade de la cámara en principio, fin y en los cortes de escena. Creo que por eso la producción, de ese momento, tiene bastante fade. Después logramos obtener equipitos y empezamos a trabajar por corte, con consolitas de edición muy sencillas y después los primeros equipos que nos aparecieron fueron de edición no lineal. Ese fue el principio.

Después de Madera Salvaje, Restrepo crea Desperdigados y Asociados, con Ana Victoria Ochoa [17] "No teníamos que estar todo el tiempo juntos, que era lo que pretendía Madera Salvaje". Aquí cada quien iba por su lado y si teníamos que hacer algo nos juntábamos y después nos largábamos. Pero tampoco hicimos mucho trabajo". Luego Restrepo se integra a Akabí, que es una voz Catía que quiere decir hacer, ver o contar. Empezó a trabajar con su familia, historias campesinas, especialmente con su padre. Durante tres años, documentó el campo de diferentes regiones de Antioquia. También laboró en la Corporación para la investigación y el eco desarrollo regional- CIERT-, con ellos realizó varios documentales de campesinos y también empezó a enseñar producción documental, guiado por la idea del video comunitario en la que la voz y la mirada es la de los otros.

[Joche] "Me dediqué a trabajar en veredas, con otro proyecto de familia que era La Escuela Alternativa de Video. Ya no éramos los protagonistas hacedores de documentales sino que empezamos a enseñary a producir a otros...Desde esta escuela, también le enseñé a integrantes de bandas delincuenciales a hacer documental, lo que ahora llaman "bacrim" [18] que en ese entonces eran bandolas o combos. Algunos de ellos cambiaron sus vidas a partir de eso; yo conozco a muchachos que eran de bandas y hoy hacen videos de reggaetón, documentales, seriados de televisión, deportes. Entonces hay pelados que cogen rápido la cosa y eso está metido en la filosofía de la escuela alternativa; cero diplomas, cero formaletes, aprenda un oficio, enamórese de él, salga adelante, ayude a la gente, y explore su sensibilidad sin tanta plataforma. El objetivo es que la persona encuentre algo que le permita sacar lo que tiene adentro sin generar tanto dolor y resentimiento.

Uno de los últimos colectivos que integró Restrepo, fue Replique taller, el cual después de un corto tiempo se desintegró.

Oscar Mario Estrada también ha impulsado varios colectivos, en 1993, junto con otros colegas creó Nickel Producciones, Corporación que continúa vigente, y desde la que se realizaron documentales como Las Sevillanas de Colombia (1994). En varias de las producciones de Nickel se rescata la memoria urbana de Medellín. Esta Corporación también produjo "Del árbol, la semilla", en torno al patrimonio artístico y cultural de la familia Vieco Ortiz [19], trabajo agrupado en una miniserie para televisión, dos exposiciones, tres conferencias y dos conciertos en escenarios culturales de la ciudad. Han producido trabajos de carácter institucional para entidades como Comfama, Alianza Positiva, Comfenalco, Universidad de San Buenaventura y Universidad de Antioquia. Entre 
el 2010 y 2011 realizaron para la Secretaría de Cultura Ciudadana de la Alcaldía de Medellín y la Universidad de Antioquia la serie de microprogramas y el documental "El Bicentenario: reflexiones, imágenes y representaciones sobre la Independencia de Antioquia y Colombia 2010-2013". Estos documentales han sido emitidos por diferentes canales de televisión, espacios culturales y educativos, regionales, nacionales e internacionales. En su momento integraron Nickel, Germán Freddy Valencia y el cineasta Carlos César Arbeláez, Director de la película, Los Colores de la Montaña (2011). En cuanto a Carlos Bernal, produjo y realizó varios de sus documentales conjuntamente con Beatriz Bermúdez [20].

Aunque se reconoce las fortalezas que se desarrollan cuando se integran colectivos para producir, al parecer su permanencia en el tiempo es difícil, en este contexto es notable que Nickel Producciones, bajo el liderazgo de Estrada, siga activo, a pesar del cambio permanente de sus integrantes.

\section{Temas}

\subsection{Ciudad / Ruralidad}

La ciudad así como el espacio rural, son temas recurrentes en la obra de los documentalistas estudiados. Bernal presenta una sinfonía de ciudad en la que la vida rural parece más grata para el espíritu y cotidianidad humana. La nostalgia de la provincia, sus paisajes, música y personajes son frecuentes en la obra de Estrada, la ruralidad urbanizada reflejan cierto cuestionamiento a la vida rural. La ciudad caótica y marginal que refleja al hombre contemporáneo es usual en los documentales de Restrepo en contraposición a los espacios rurales en los que la vida pasa jocosa y de manera natural. En ambos contextos los perros acompañan a los humanos.

Socioculturalmente el antioqueño es reconocido por su afecto al campo, "montañero" se les dice, porque la región está rodeada de montañas, esto también alude a la forma campechana de hablar con expresiones como "marrano" para referirse a una persona que no le atina a hacer bien lo encomendado. La nostalgia por la vida campesina está plasmada en poemas, canciones y diferentes obras artísticas de los pobladores de esta región. En la obra de los documentalistas estudiados, la referencia al campo, la vida rural no es la excepción.

\section{- Ciudad sinfónica}

Carlos Bernal, en "1526 metros sobre el nivel del mar" (2004), se pregunta por el impacto de la sociedad de consumo en el equilibrio ecológico de ésta. En este documental muestra el Metro, el moderno transporte urbano de Medellín; los oficios callejeros y la cotidianidad mediática de la ciudad, a la vez nos presenta lo cultivos orgánicos que se producen en la ruralidad cercana de la urbe; el ritual de un desayuno, en el que una abuela remoja un buñuelo en el chocolate y conversa con su familia; la visita de los vecinos y la conversación de campesinos de manos fuertes, que usan ropa de trabajo y botas de caucho. En la ciudad de Bernal, transeúntes nunca vueltos a ver, el emblemático edificio Coltejer, [21] y Argos [22], símbolos de lo que fueran las industria más sólidas de la región, los textiles y el cemento. 


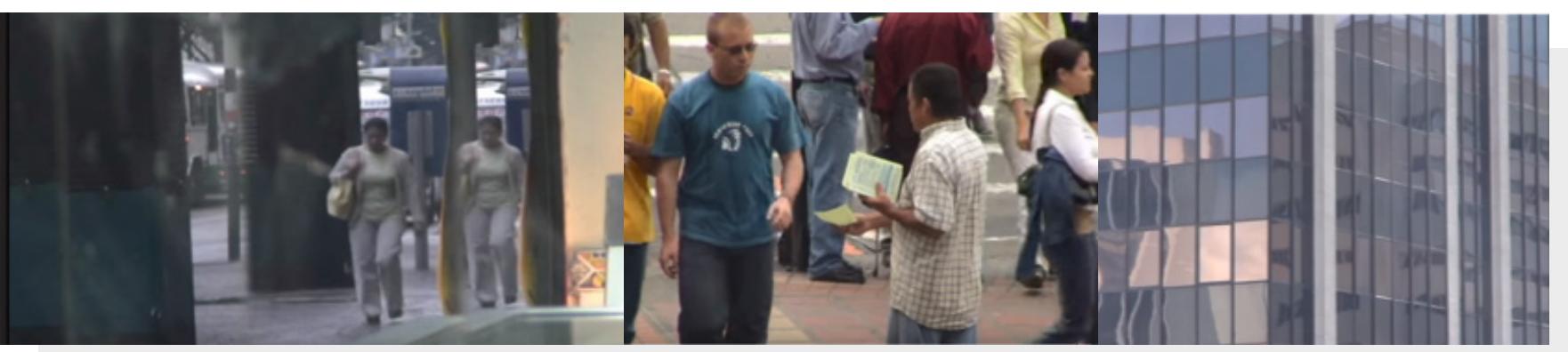

1526 metros sobre el nivel del mar" (2004) Recuperado de: https://www.youtube.com/watch?v=pK-omBzr1Ss

Cada cosa, cada lugar, cuenta la cotidianidad de una población atada a otra. Bernal interpela los códigos de ciudad y de campo, los re-significa. Las acciones de este documental son ícono de la cultura local. El agricultor, con la sinceridad que caracteriza al antioqueño expresa:

"La verdad en Medellín no me veo viviendo en algún tiempo. Que me toque irme a vivir allá por razones de fuerza mayor, pero no está dentro de mis planes. ¿Por qué razón? porque la verdad cuando voy por allá a Medellín me siento como encerrado, estresado por la contaminación, por el ruido, el agite de todo el mundo que se vive en la ciudad. En cambio uno acá vive tranquilo, se acuesta y nadie lo molesta. No hay un bus que esté pitando, no hay la gente que esté gritando.

(Documental 1526 metros sobre el nivel del mar, minuto 23:10)

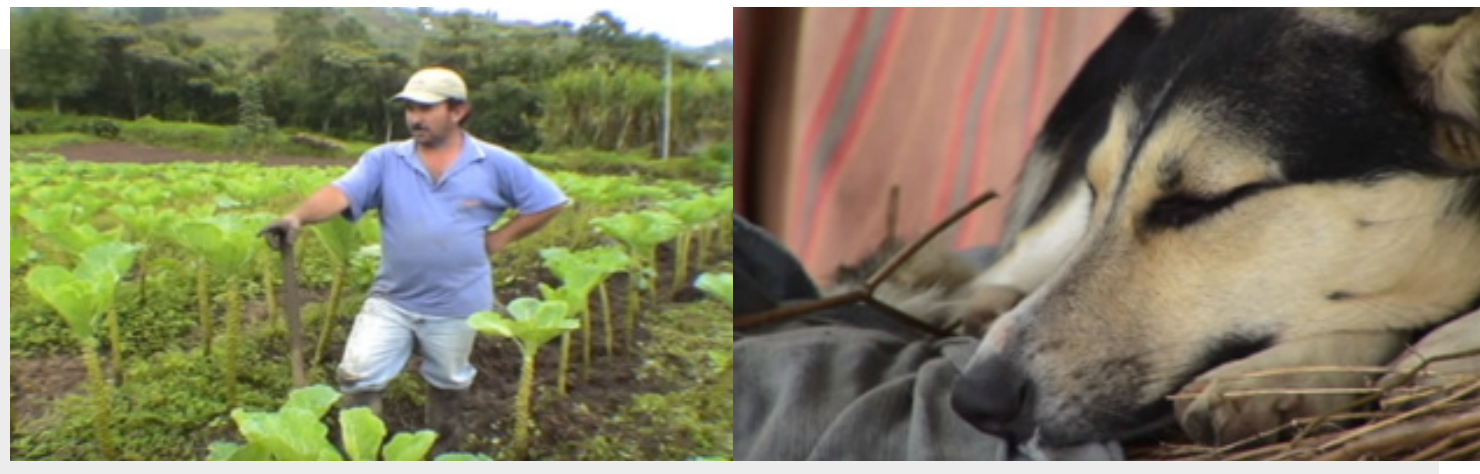

En este documental Bernal es latente, no quiere ser explícito, ni seductor. Creemos que estamos ante la clave del video de marras: su contenido no es lo que muestra, sino algo más lo que sugiere. Esto es un asunto de polisemia, de significante y lectura en un sentido recto e interpretativo, de asociación, que puede ser accesorio pero se revela indispensable para su entendimiento. 


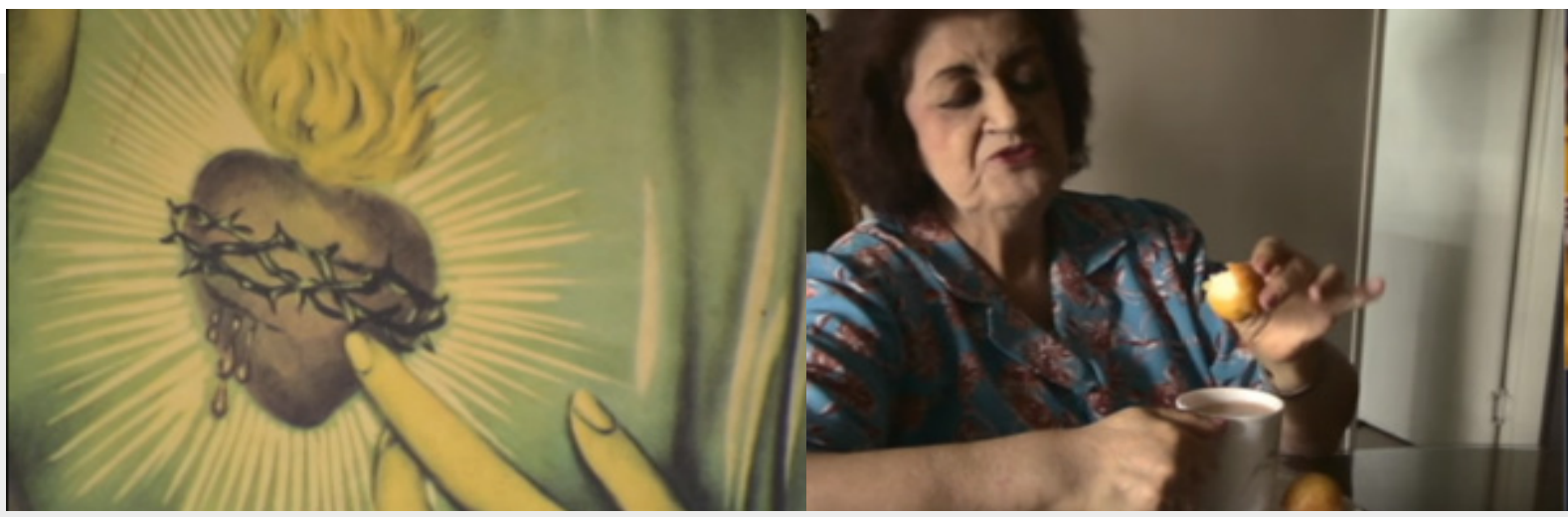

Textura del cuadro del Corazón de Jesús, como atrezzo para dar cuenta de la idiosincracia antioqueña por medio de símbolos.

Las interpretaciones que se pueden hacer no salen del orden especulativo, porque se trata de mucho más que de un cúmulo de imágenes "contemplativas": hay un orden, para empezar, seudo-cronológico, o ficticio de avance en el tiempo, o sea, se pretende reconstruir una jornada en Medellín, al estilo de las famosas "sinfonías de ciudad", como El hombre de la cámara o, recientemente, Suite Habana. Pero esta conexión de simultaneidad y contigüidad esconde otros secretos, porque la exposición alienta a la inquietud por las resonancias de todo cuanto se ve, la violencia, la relación entre el campo y la ciudad, las expresiones de la cultura popular. Actos de habla van de lo muy formal a lo netamente espontáneo, delicadamente capturado, como se da en la escena del billar donde amigos departen y juegan:

"Oiga! Pa que cuente cuando le robaron el marrano. Yo no le perdono que me haya robado ese marrano porque ese marrano era muy galgo. Ese marrano adelantaba mucho."

O en el noticiero radial ¿Cómo amaneció Medellín? en el que se escucha:

"Explota carro bomba al lado de una iglesia en Medellín. El sacerdote y varios feligreses heridos. [El afectado, comenta] Empezaron a caer lámparas, los vitrales, todo. Entonces todo el mundo nos tiramos debajo de las bancas. [Locutor] Estación de policía y más de 50 locales comerciales también resultaron averiados por la explosión. Capturados más de 40 guerrilleros en 3 municipios de Antioquia. Este lugar sacudido por un carro bomba este fin de semana, fue hoy centro de una concentración de paz".

La violencia en la ruralidad también es documentada por Bernal en Fue Anunciada (1988), allí hace un retrato de los autores de la masacre que los paramilitar denominados "Muerte a Revolucionarios del Noreste", liderado por Fidel Castaño, perpetraron en Segovia - Antioquia. Los testimoniados dejan huellas imborrables de lo que es ser sobreviviente. Bernal y Bermúdez registran la cara espantada de la población, los charcos de sangre esparcidos en la plaza del pueblo, pájaros enjaulados y algunas iconografías encasquetadas en fachadas y edificaciones locales. 


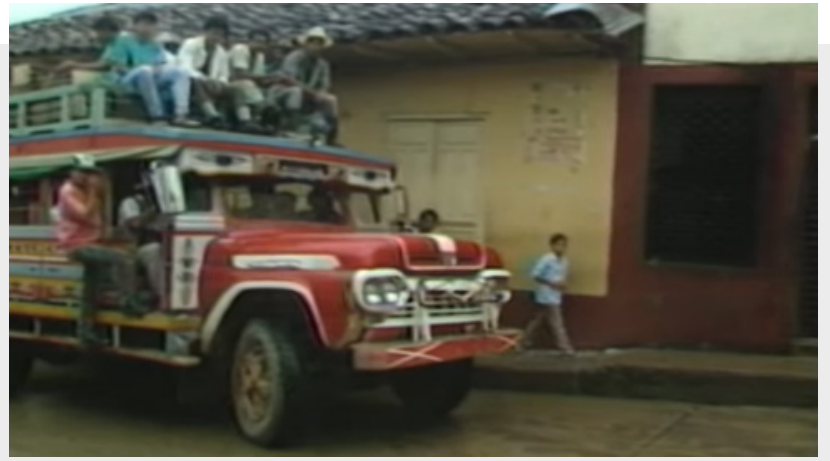

Fue Anunciada (1988)

Recuperado de:

https://bit.ly/2rb2qD3

En relación a la grabación de este documental, comenta Bernal "Ahí, los nervios dominaban cualquier intento estético y dramático. Era el registro, una especie de acto ennoblecido para ser de alguna manera testigos de esa barbarie y denunciar."

La ciudad y el campo de Bernal siguen su tránsito hacia realidades más caóticas, pero no por ello dejan de ser bellos y entrañables, en estos los colores primaverales se interrumpen por la violencia, el concreto y el hierro de los medios de transporte, allí la radio y la televisión están presentes. Desde Acordeón de papel (1991), en el que Bernal registra el trajín de las familias recicladoras, en la ciudad capital de Bogotá, se nota una preocupación por temas medioambientales.

\section{Acordeón de Papel (1991) \\ Recuperado de: https://bit.ly/343Kadv}

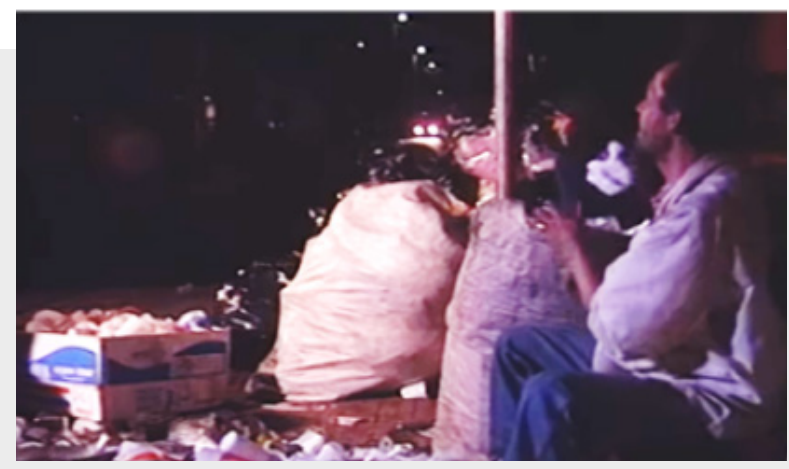

\section{- Ruralidad urbanizada}

Magistralmente Estrada en la "Tienda de Juan José" (2008) describe un punto clave en la historia del Municipio de Caldas. En ese documental clientes, vecinos, historiadores, recuerdan los días en que en dicha tienda se distribuía la leche fresca que llegaba de la fincas cercanas. Ahora en medio de una partida de ajedrez, una buena conversación, música y canto se evoca una atmósfera y universo vital. Algunos de los nuevos visitantes de la tienda, están vestidos a la usanza, sombrero, alpargatas, carriel y poncho, lo que es aprovechado y captado en el video.

En este documental Leonel Ospina, el compositor del "El jardinero", interpreta su canción mientras en el lugar, unos bailan, otros juegan ajedrez, beben licor y otros más ven el partido televisado de fútbol. También se observa al lustra botas o embolador, al acordeonero y a un perro que recorre tranquilamente el lugar. "Mazito", uno de los personajes del documental conecta sus recuerdos de la tienda con los del Ferrocarril de Antioquia y la muerte trágica de su madre. "Mazito" tomándose un trago en el lugar dice: 


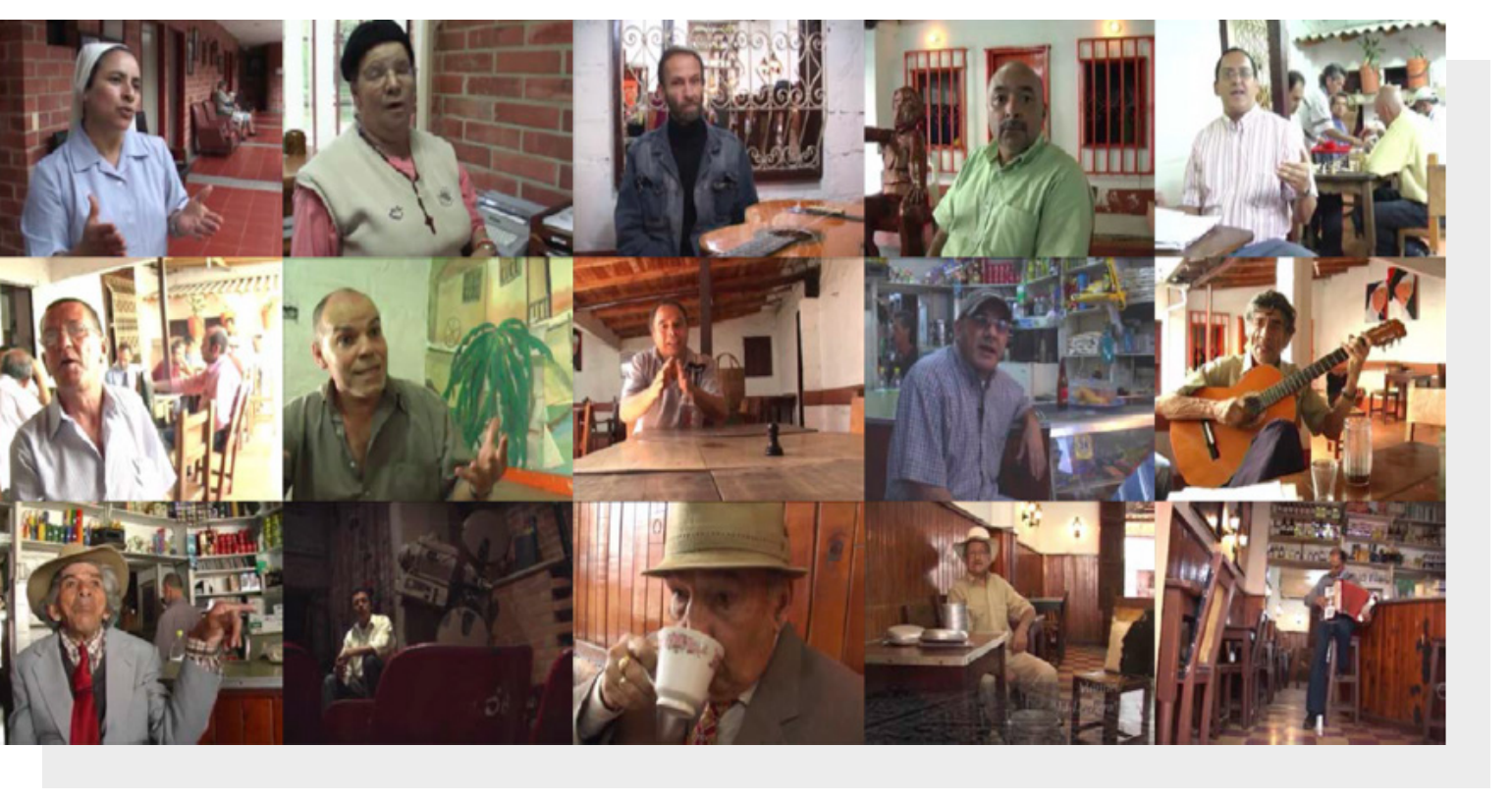

"Yo conocí, con permiso [se toma un trago] yo conocí el tren, yo era cadenero así "culicagado" [23], el tren andand o y yo a la carrera por encima recorriendo y tocando la campana por si hubiera un peligro ahí mismo iban y los paraban con mañita. El tren mató a mi mamá, me tocó arrecogerla y del colegio la arrastró dos cuadras y media, y entonces a mí me tocó arrecogerla por puñados en sangre fría".

Luis Fernando Castañeda, uno de los actuales clientes de la tienda dice:

"...yo suelo venir [a la tienda] en las mañana, ensayo guitarra, hago unos ejercicios en partitura, eso sería dos horas, luego voy a casa y busco algo de comer, y estoy regresando tipo 2 o 3 de la tarde. Ya encuentro la gente de ajedrez aquí y bueno, también hago parte de esa actividad y me pongo a jugar con ellos...También de pronto cantamos, nos entusiasmamos y tomamos la guitarra y hacemos algunas canciones. Esto la verdad, se nos va el asunto hasta la hora de la noche 10,11, 12 incluso hasta el cierre... A veces nos tienen incluso, que sacar de aquí. Prácticamente sacados...Esa es más o menos la dinámica de toda la semana".

Otras personas que dan testimonio de sus experiencias en la Tienda de Juan José son: Iván Arango Mejía "El profe", Diego Posada "Gallardía", José María Ruiz, Mauricio Tamayo, Hernán Gómez, Luis Fernando Correa y Mario Montoya. Ellos comentan que en la tienda se hablaba del poeta Ciro Mendía, de la música de Juan Arvizu y Alfonso Ortiz Tirado; Rodrigo Morales señala que años atrás se hablaba acerca de los periódicos El Preludio y El esfuerzo. Mario Montoya Cuartas comenta:

"...personas que han estado por fuera en Estados Unidos, en Europa hace 15 o 20 años, recuerdan venir acá por la leche, esa es la constaste en el recuerdo.. Además, dice [A la tienda] "venían [los campesinos] a traer las razones de la finca, a dejar el apero el uno al otro; a contarse las historias de lo que pasaba en las fincas, a buscar trabajadores... La tienda en ese momento y hoy sigue siendo un puerto". 
El documental destaca los testimonios de Josué Sánchez, la Hermana Gertrudis Padilla y Marta Livia Cardona en torno a la donación de los terrenos que Juan José hizo para que se construyera el asilo de Caldas. Todos los testimonios se apoyan visualmente con fotos antiguas, imágenes nocturnas, pinturas del entorno de la tienda e imágenes del Municipio (calles, casas, parque y asilo). También imágenes del Ferrocarril de Antioquia, de Amagá y del Bogotazo. Se observa en el documental videos de archivo a blanco y negro de una plaza pública, una avioneta, un fragmento de la película El pianista de Roman Polansky. Igualmente fotos del presidente del Salón Minerva Roberto Muñoz Londoño y el libro de actas de 1930, de ese lugar; imágenes de Jorge Eliecer Gaitán, Juan José Posada, un cura y sus feligreses y de las bandas musicales La sirena, La lira.

Estrada, elude inteligentemente la hagiografía de un personaje para apenas advertirlo en sus poses más significativas, sonriendo en una foto que hay en su tienda, o en los rasgos más memorables para los entrevistados que lo recuerdan, como un fastidio por las discusiones sobre política. Así lo tenemos como un anfitrión que posibilita lo que sí es importante para el video, que es el conglomerado de gente que participa en la creación de un lugar significativo para la sociedad, donde uno puede ir y sentir que pertenece, escuchar música, descansar; hablar; o cantar; sin necesidad de hacer más nada, como insisten los personajes en una compleja y sobria arquitectura de intervenciones, fruto de una edición íntimamente relacionada con el asunto.

En la actualidad, Mario Montoya Cuartas continúa esta cotidiana tradición de preservar y mantener vivo un lugar que alberga tras sus muros, no solo los fantasmas de la memoria, sino la utopía de un lugar para el encuentro. Esta tienda es uno de los pocos espacios que quedan en este Municipio que a pasos agigantados se convierte en urbe.

En Hilos de Libertad (2003), Estrada nos muestra a Jericó, un municipio al suroeste de Antioquia. En este documental las actividades están alrededor del festival de la cometa, se abordan temas como: la expresión popular, el arte, la cultura, la lúdica y la recreación. Se destaca el cuidado de la composición fotográfica y el montaje de la película, que a través de un ritmo casi musical, le permite al espectador contemplar la belleza de la cometa como artesanía y al mismo tiempo ser testigo de la alegría y unidad del pueblo durante su fiesta anual.

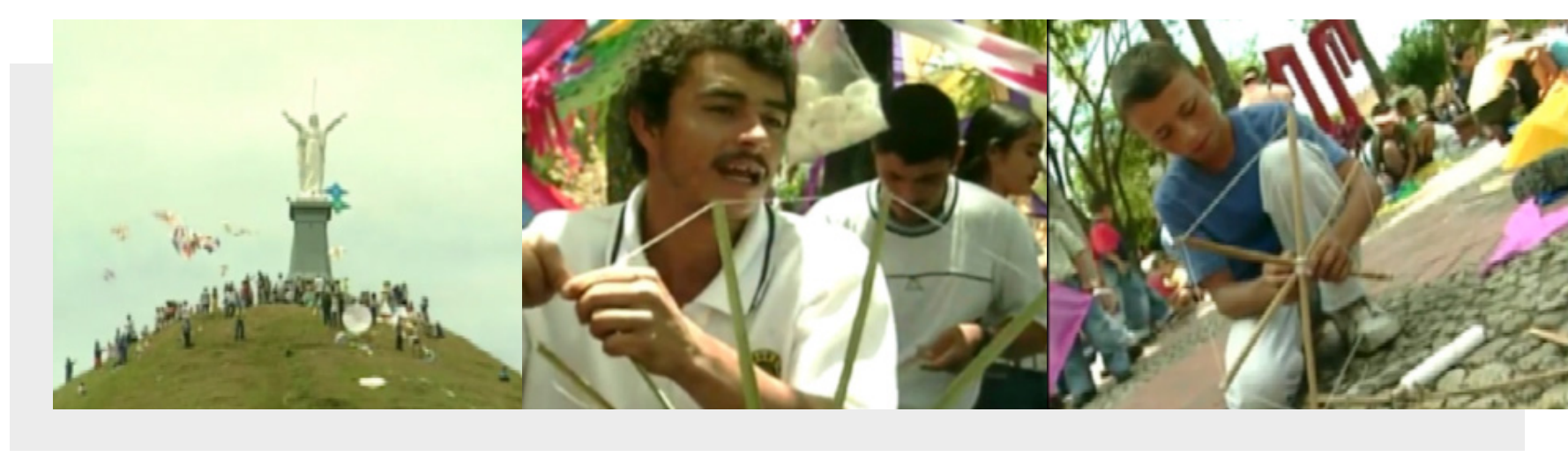

En el documental, los niños en compañía de sus amigos, sentados en el parque del pueblo, fabrican las piezas que posteriormente alzarán en vuelo. También los adultos se unen entusiastas y muestran con orgullo la artesanal filigrana de motivos geométricos cuidadosamente dibujados en papel y montados con firmeza sobre delgadas varillas de caña brava. La cámara se mantiene al hombro y sus movimientos son espontáneos, siguiendo a los personajes y la dirección de vuelo de las cometas, 
por eso hay un grado de improvisación que permite respetar el flujo natural de las acciones y registrar momentos que serían imposibles capturar en el caso de contar con una planeación estricta de movimientos de cámara.

Las imágenes emblemáticas que puntúan el documental son de una belleza propia del asunto pero también del encuentro con un camarógrafo y un formato que se adecuan a los fenómenos con cualidades especiales (los iris de la imagen cuando la cámara graba el sol, por ejemplo, no parecen de ninguna manera un defecto o algo indebido o incorrecto, sino al contrario: indispensable y tan bello como mirar al sol y que las pestañas lo restallen). En cierto sentido son imágenes que se integran a todo lo demás de muchas maneras, por ejemplo a las secuencias que muestran todo lo que hay detrás del festival: la manufactura, el comercio, la pasión de hacer y crear... Pero aún más son imágenes que se desprenden del contexto y se vuelven autónomas, justo como el hecho de elevar una cometa tal como lo describen sus aficionados: un acto de libertad, en que se vuela.

La gente del pueblo, turistas y visitantes atraviesan las calles del municipio, rumbo al morro, la imagen de un cristo con las manos abiertas los recibe en la cima de la montaña, lugar en el que por años han lanzado al cielo sus sueños, allí la música de la comparsa ambienta la tarde de familias enteras que se reúnen en torno al concurso de cometas mientras las fachadas de las casas en el pueblo se visten de fiesta. En el parque central del pueblo también ocurren escenas importantes, como el desfile comunitario. Se hace referencia a la arquitectura del municipio a través de sus calles y escaleras antiguas, puentes, balcones y ventanas. Finalmente, en el interior de las casas, donde se realizan algunas de las entrevistas, también se destacan espacios como los largos corredores y la decoración con cuadros religiosos, pinturas, retratos y macetas propias del estilo y la idiosincrasia del suroeste antioqueño.

Si consideramos que la imagen final del documental es un soldado llevando una cometa caída para un niño, nos damos cuenta de la significación profunda de este trabajo, que no enfatiza jamás en ese contexto pero que le da, incluso a la obra de Estrada en conjunto, poblada de soñadores y artistas igual de románticos y en apariencia irresponsables como los que elevan y promueven elevar cometas, un tamaño de considerable magnitud en la cultura y la historia de la cultura antioqueña.

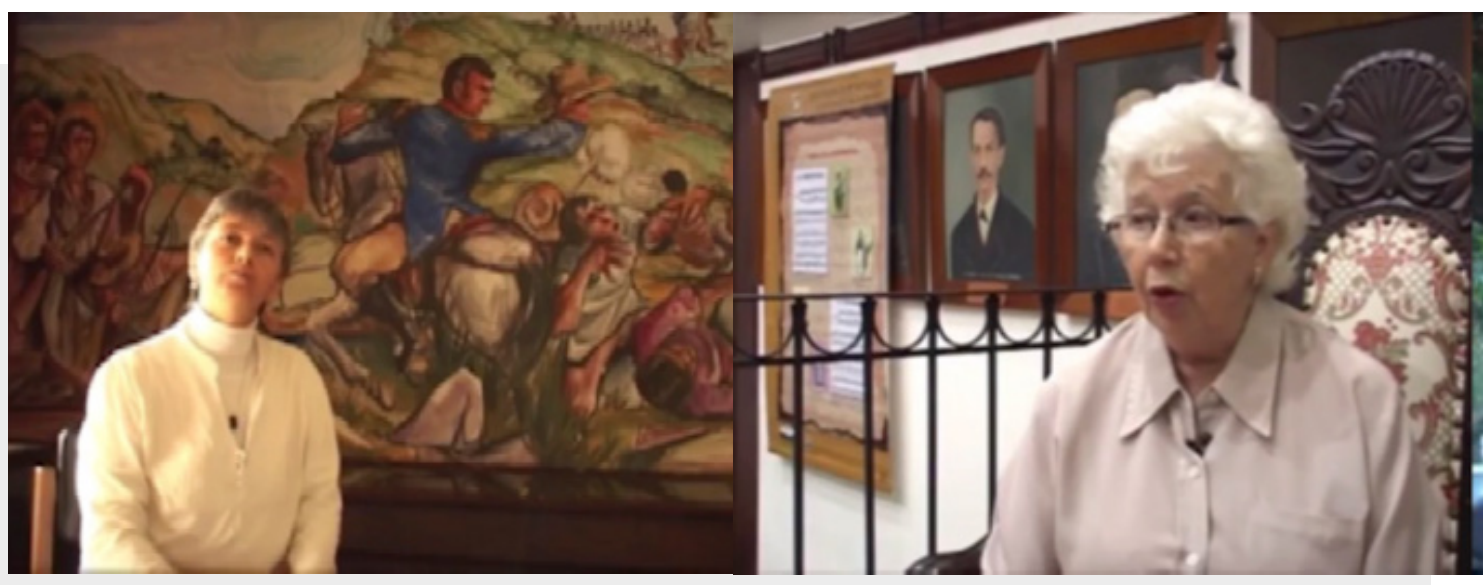


La región antioqueña, también es abordada por este documentalista en "La Independencia de Antioquia" (2011). Aquí la historia de esta región es abordada por académicos que reflexionan sobre el significado y las implicaciones de la independencia, contextualizando su discurso sobre la dimensión temporal: presente, pasado y futuro de la provincia. Inicialmente se plantea una reflexión sobre el concepto de independencia, luego se hace una contextualización sobre las causas que derivaron en la crisis del imperio español, el descontento de las colonias frente a las reformas instauradas por la corona, y la oportunidad de independizarse. Posteriormente, historiadores y académicos destacan el legado histórico de la obra de artistas como Pedro Nel Gómez, que retrataron el espíritu del pueblo antioqueño a través de la pintura, la escultura y la arquitectura aún conservada en los municipios que lideraron el proyecto independentista; cuya organización social y solvencia económica, les permitió financiar a los ejércitos rebeldes, en una época donde apenas se estaba comenzando a pensar en la posibilidad de constituirse la república de Colombia. Un entrevistado comenta:

"Algunos dicen la patria boba y creo que en ese término fuimos educados todos, pero no fue una patria tan boba, se estaba definiendo, marcando límites, le dio a la gente la conciencia que podía definir su destino. Lo definió como desgraciadamente en Colombia hemos definido muchas situaciones, a punta de guerra, pero eso se produjo por el grito del 20 de julio".

Múltiples son los escenarios que se visibilizan en el documental: la Academia de Historia Antioqueña, el palacio de la cultura "Rafael Uribe", así como las fachadas de las calles y los parques de municipios como Marinilla, Rionegro, Medellín y Santafé de Antioquia.

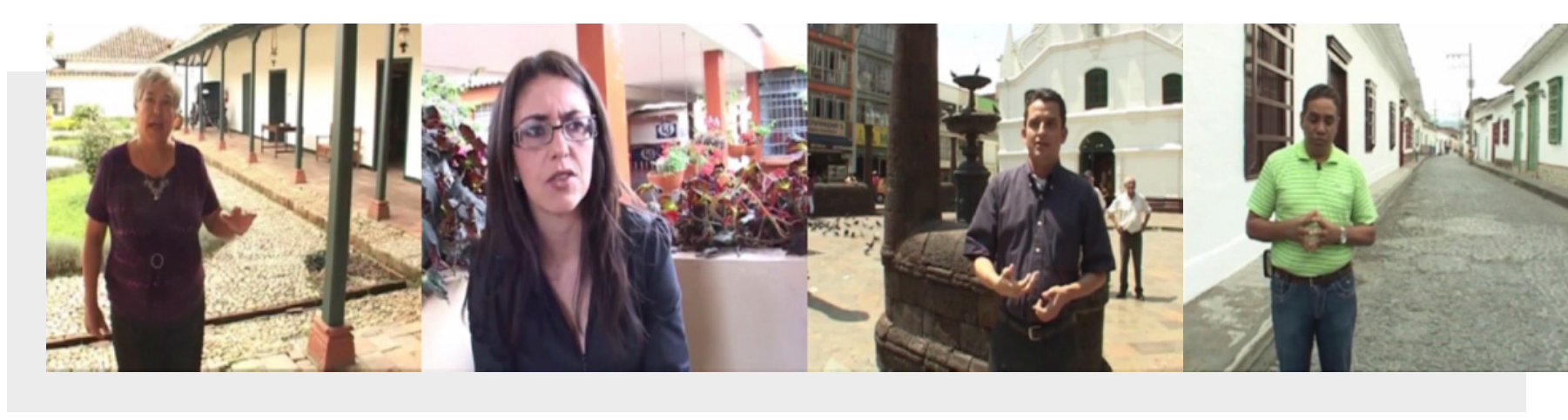

Al final, se hace revista de los héroes que dejó la independencia de Antioquia, y se enfatiza en la posición privilegiada de la provincia, que con su capacidad para financiar la campaña libertadora, mantuvo las batallas militares al margen de su territorio. Sin embargo, se reconoce la importancia de los contingentes enviados a defender la gesta militar y de hombres como José María Córdoba, que dio su vida luchando contra los españoles. La imágenes de apoyo muestra arte y arquitectura de la época.

\section{Ciudad, barrio y campo como "lugares", "no lugares"}

La ciudad de Restrepo, parece que fuese un "no lugar"[24] en el sentido de Marc Augé, pero que al ser captada por el lente se convierte en un lugar, esto es ese espacio antropológico, vital en el que nos relacionamos; quizás el lente nos devela 
que no hay no lugares. En Caw pax (2004), se visibiliza una ciudad sentida por cuatro jóvenes "amanecidos" que se encuentran en un bar del centro de la ciudad; dos mujeres, una argentina y el dueño del bar. Ellos reflexionan a manera de trance. Una de las mujeres dice:

"Vivimos en un Estado [Colombiano] ultraderechista, pero tenemos un lugar en esta ciudad [Medellín] donde podemos venir a fumar bareta, perico, a bailar".

En cámara un cartel en el que se lee: "Nuestras alas no pueden estar sujetas a marionetas mecánicas, resistimos a la flecha que ataca y a los ejércitos que asesinan". En medio de ese bullicio un músico toca la trompeta. La joven del bar dice que los paramilitares son muchos y es a ellos a quienes la comunidad le pone las quejas. En esa ciudad habitada, percibida, narrada hay "paramilitares" [25], comunas [26], mafias [27], falta educación, los medios de comunicación "venden" basura, realities, es decir show, espectáculo, emociones ridículas, una vida "light" y la idea de que el triunfo se logra de la de la noche a la mañana.

Restrepo muestra imágenes de Medellín con efecto de espejo, mientras tanto en un concierto los jóvenes poguean [28]. Joche [El realizador] sentado en el piso, se pone de pie y camina hacia la cámara. Esta registra desde el suelo en contrapicado el cadáver de un perro con la cabeza aplastada. En otro momento el documental muestra imágenes del metro cable y de fondo la conversación en la que la joven del bar dice que Pablo Escobar fue visto como una solución a sus necesidades básicas. La argentina le responde que a ella le han dicho personas de los barrios de Medellín que Pablo Escobar les dio la escuela.

El barrio, urbano -rural, también es visibilizado por Restrepo, en "Irrevherencia"" (2012), en ese barrio, que queda en la periferia de la ciudad, hay "piscos", niños y droga. Es un barrio donde la gente transita al igual que Cesar, el protagonista. Allí hay pobreza, conflictos, guerra, cabritos, conejitos, buses; en estas calles se juega, se ve y se escucha fútbol, mientras un girasol es movido por el viento. Este barrio, por supuesto tiene historias, como la que César cuenta:

Yo un día mandé a un niño a comprar licor, y que lo que le vendieron fue alcohol industrial, y esto le causó la muerte a uno de mis amigos.

Cesar al parecer cambio su vida, no se sabe las razones de esto, quizás porque encontró la palabra de Dios, ya que hay varias referencias a ello en el documental; y es que en los barrios marginados de Medellín, parece ser que el Cristianismo ha calado como la solución de vida para soportar los avatares terrenales. En este documental aparece un personaje de la nada y dice "padre bendícenos porque tú eres un Dios de amor", otro predica, Dios ayuda a esta gente a que tengan fe y esperanza en el Dios de la paz y no en el de la guerra.

En ese barrio marginal de Restrepo, también hay niños que juegan entre los árboles. Un excombatiente en Villatina, un lugar cercano al Cerro Pan de Azúcar, cuenta que ese sector estaba abandonado y que él hacía parte del conflicto armado hasta que se desmovilizó al igual que las autodefensas y empezaron a impactar el barrio, con nuevas propuestas, y se convirtieron en líderes comunitarios y referentes de los niños y de las nuevas generaciones. Después en entrevista con el realizador de este video, comentó que este sujeto había vuelto a delinquir. 


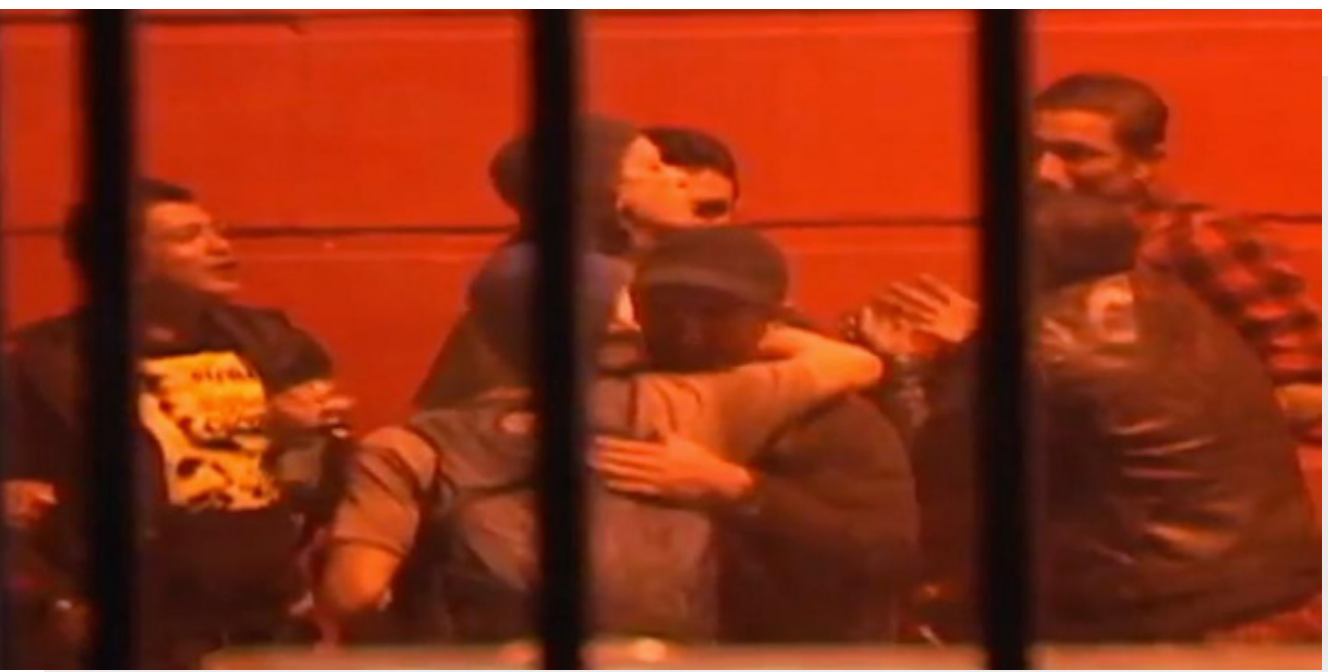

Con imágenes captadas en diferentes tiempos, contextos, Restrepo reconstruye lo que para él es ese barrio, punkero, poguero. En tal sentido podríamos decir que se trata de un realizador de videoarte o un periodista que hace editoriales audiovisuales para expresar sus objetivos, su filosofía. "La edición que hace Joche de su material es irracional, pero no indiscriminada, sino que entrecruza realidades con una lastimada certidumbre, la de que la cordura de la civilización es un sueño infame. Con esto regresamos a su capacidad de escucha y a su respeto por la gente: nadie puede acusar a José Miguel de "hacer uso" de los testimonios que consigue, pues él demuestra ser conciente de que valen por sí mismos, y su edición parece no querer mezclarlos, sino más bien dejarlos intactos, de lo cual emana, como dicen Gutiérrez y Aguilera, la propia visión de Joche como artista... Una visión, en este caso, colapsada" [29].

Este es un largometraje en todo rigor, y en la línea del documental más experimental y, al mismo tiempo, crudo o descarnado, pedestre, de la historia del cine mundial, como lo es por ejemplo el famoso Gimme Shelter [1970] [30] de los hermanos Maysles, The Last Waltz [31] de Scorsese, Woodstock [32] u otros legendarios conciertos que tuvieron el acierto de estructurar sus películas tan creativa y significativamente como lo exigía el contexto de un hecho crucial en la historia de la cultura de masas (el fin del hippismo en Altamont, el adiós entre The Band y Bob Dylan, el punto culmen del Flower Power, en el orden de los ejemplos citados), aquí podemos estar seguros de que se rescata justo el ámbito de la cloaca, pero con un sentido humano que constantemente retuerce el cadáver de los roedores que encuentra, y a los que da cristiana sepultura, para revivirlos.

En este documental no hay estructura, no hay prelación de ningún eje. Los espacios donde no hay música, están plenos del espíritu punk, pero además de un espíritu punk propiamente medellinense, auténticamente medellinense, barrial, extramuros.

La ruralidad de Joche, al igual que la ciudad y el barrio es un lugar de paso, ese "lugar", "no lugar" que capta en Aristas de la Escalera (2011). En éste se muestra la visita que el documentalista y otros colegas suyos hacen a la casa de Norbeli y su familia, una mujer del campo que tras la muerte de su esposo, decide ponerse ella misma a manejar ese medio de transporte al que también se le llama "chiva". 


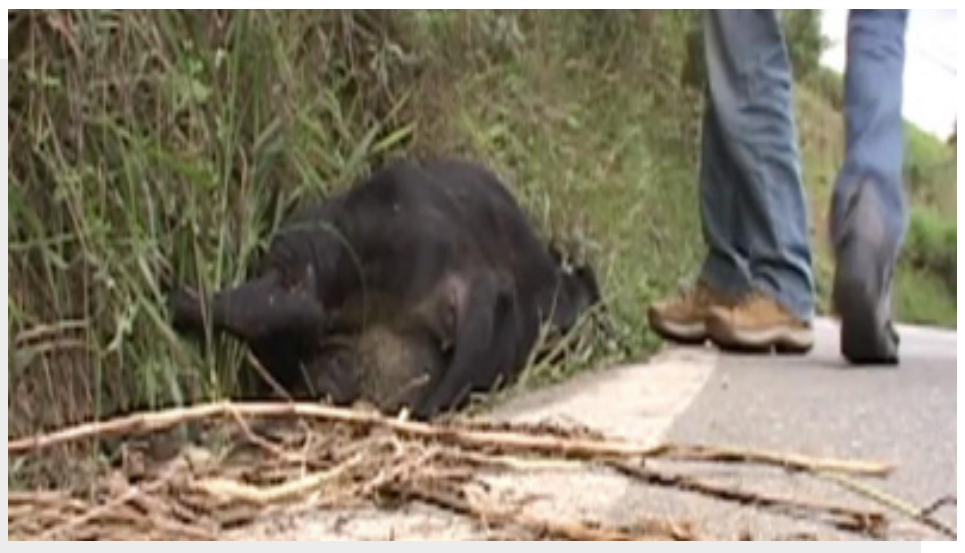

La vida del campo es captada y vivida por el mismo realizador a quien se le ve desayunando en la cocina de la casa, también recorriendo el jardín. Ese retrato de la accidentada vida del campo se refleja en un novillo que al caer de una ladera aparece agonizante en pantalla, también en la necesidad de la venta de los productos que se cultivan sin resultado favorable. A pesar del drama la gente se percibe alegre y chistosa. La conductora de la escalera dice:

"Si uno va a cien ahí se despelucó" [para indicar que no puede conducir a mucha velocidad, porque se podría producir un accidente].

En medio del paisaje campestre las mujeres se muestran contentas realizando las labores domésticas y también se perciben felices cuando les toca ejecutar funciones como la de conducir la escalera. Al referirse a la decoración de su "chiva" la mujer dice: "... me gustaría mucho dibujarle la virgen de Guadalupe que es mi patrona" y agrega "Meramente el decorado de las rayitas vale tres millones de pesos".

La dinámica e interacciones entre los visitantes, la familia campesina y los agricultores es constante. Este documental se podría catalogar como periodístico, pero va un poco más allá ya que no interesa solo la entrevista con la conductora, sino que captura un momento en el campo. Mientras la chiva está parqueada, un pájaro carpintero está en acción, un águila pasa, una mujer se coloca su celular entre los senos, un hombre vende chócolo, otra cocina y varios camarógrafos con chalecos, lucen el logo del canal regional Teleantioquia. Hay escenas dentro de las escenas.

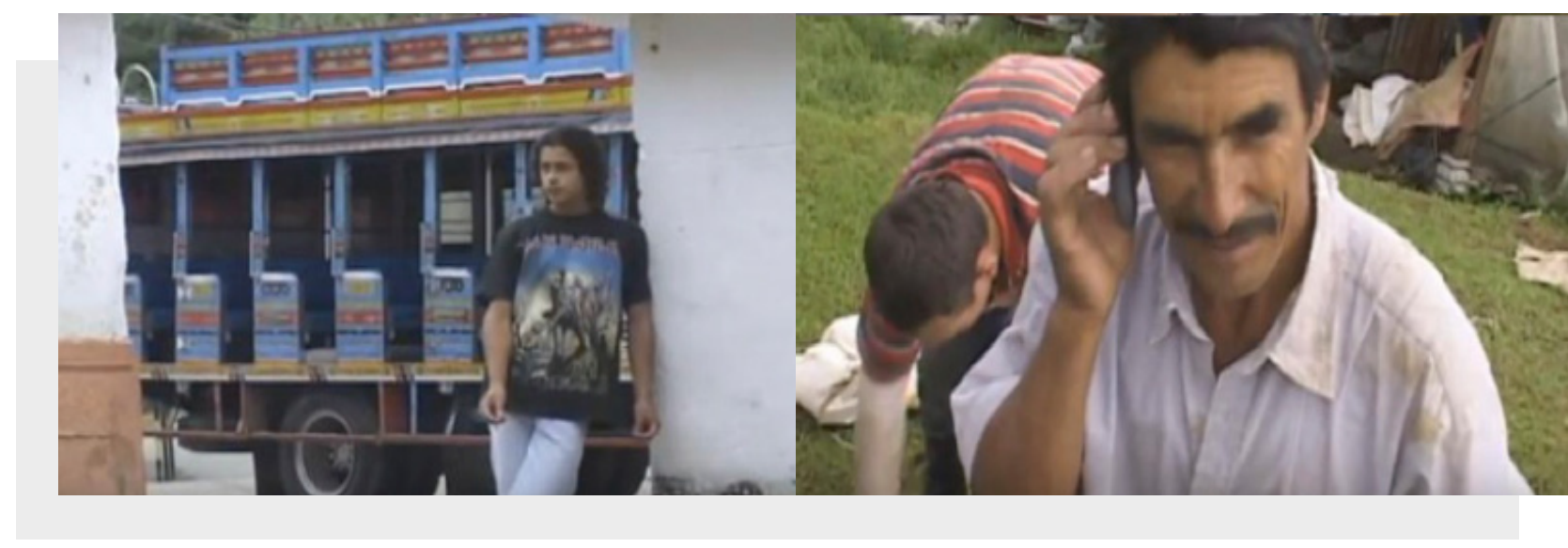


El hombre que vende el chócolo, habla también por teléfono celular, lleva puesto en su muñeca un reloj y en el bolsillo de su camisa guarda un paquete de cigarrillos Marlboro. Nurbely Patricia, la protagonista, al final del documental se coloca sus gafas oscuras. Estas acciones e imágenes, muestran una ruralidad en la que el estilo de vida urbano ha penetrado y pasa desapercibido o está naturalizado.

En Arví engaño (2011) [33], Restrepo, presenta una serie de entrevistas a campesinos de la zona que se sienten afectados por la construcción de este parque ecológico, que actualmente presenta una amplia oferta de recorridos guiados, avistamiento de aves, senderismo, siembra de árboles, y se ha constituido en visita obligada para extranjeros y nacionales.

En el documental los habitantes de la vereda Mazo se quejan de la administración del parque, ellos hablan de los problemas para la economía campesina, retratan la vida cotidiana en el campo en el pasado y presente. También en el video se crítica a los medios de comunicación, a los turistas y a la Alcaldía de Medellín.

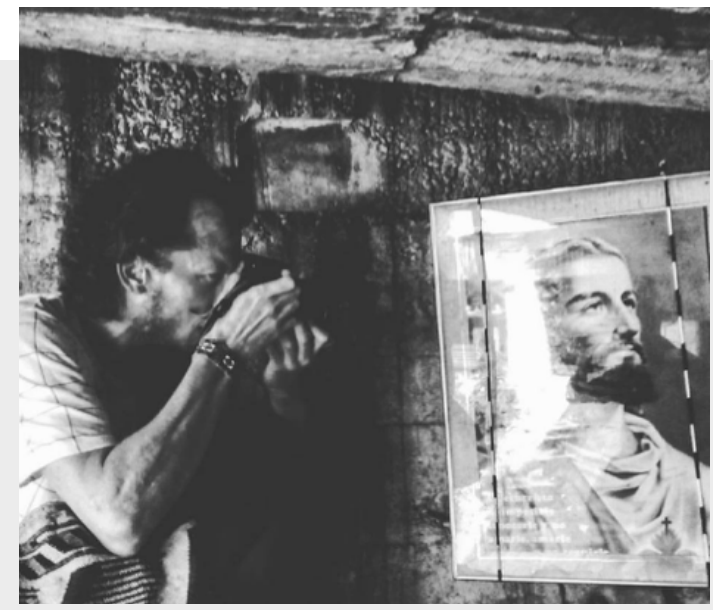

Grabación de "Lagua Bendita"

Foto: Juan Gonzáles

Mientras se presenta el testimonio de un líder comunal, se muestran pájaros en una jaula y gallinas comiendo maíz. Los perros juegan, las anfitrionas sirven café, de una chimenea sale humo, este elemento está presente durante todo el documental. Se enfocan fotografías de apoyo de lo que está en las paredes de la casa, los cuadros, incluido el del Sagrado Corazón de Jesús. Láminas de la iconografía campesina popular y señalítica de Arvi. También se registra una avenida en la que hay mucho tránsito de vehículos que se combina con zonas verdes, con lo que se comunica la idea de que se está en una zona campestre cerca de la ciudad, y a la vez se señala la invasión que han sufrido los campesinos en su espacio vital.

María Leticia Gallego Vásquez, una de las campesinas entrevistadas dice "Cuando yo estaba pues más chiquita había jardineras muy lindas y la gente de Medellín venían a que les vendiera la flor, vivíamos bueno, cogíamos victoria, cidra, de todo, de todo, lo que nos provocaba hacer, eso lo hacíamos". 
Este relató nostálgico lo hace en medio de una gran sonrisa. En este video se utiliza el fade a negro; la mayor parte del montaje está hecho con corte en seco. A ese drama por el campo que da paso a la ciudad, a los turistas, se suma la tragedia o melodrama del sacrificio que se hace en la fiestas navideñas del marrano.

En el documental La Marranada (2006) se presenta la celebración de la navidad, en ese ritual que se supone llama a la alegría y la unión familiar se da muerte a un cerdo, cuyos gemidos se escuchan quizás como un llamado a la irracionalidad de un festejo o como revelación sacramental de su inhumanidad de esta celebración antioqueña, que Restrepo capta como una trasmutación de un discurso salvaje civilizatorio. Los hechos ocurren en una Vereda. Este documental es un sacudón, físicamente hablando, y este sueño es una obra, en términos formales y racionales, en un sentido sagrado, un arte no romántico como rótulo, sino como retorno a lo primordial, y solo vanguardista en tanto novedad inclasificable.

\section{Conclusiones}

Se llega a ser documentalista por diferentes razones y motivaciones, según este estudio, entre las más contundencia están: contar historias, expresarse a través del audiovisual y la formación en comunicación. Aporta sustancialmente a la consolidación de este oficio, los ambientes, contextos audiovisuales y culturales a los que se está expuesto así como las experiencias académicas a nivel internacional, el reconocimiento de profesores 0 instituciones y el auto-reconocimiento de las habilidades, capacidades para la creación documental. La conformación de colectivos para producir aparece como una de las maneras que permite desarrollar y consolidar capacidades para el ejercicio profesional, tales como el manejo de equipos técnicos, trabajo en equipo, creaciones colectivas, reflexión y auto-reflexión del quehacer, abordajes de temas así como la administración de recursos. Sin embargo se observa dificultad para la consolidación y permanencia en el tiempo de dichos colectivos, presentándose como principal inconveniente la conciliación de las diferencias de estilos e intereses y la sostenibilidad económica de estos.

La vida rural de Antioquia se registra con nostalgia y con un sentido de pérdida de zonas que a paso a paso se urbanizan (Estrada), también como lugares en los que paradójicamente hay más vida (Bernal; 1526 metros sobre el nivel del mar, 2004) y muerte (Bernal; Fue Anunciada, 1988). Para Restrepo en el campo, hay más esperanza a pesar de todo.

Estrada, documenta el ideal de la convivencia humana. Un pueblo como Caldas, un lugar como La tienda de Juan José (2008), en el que la gente se encuentra con otros para conversar, festejar, dejar y recibir recados con mensajeros humanos, cantar, hacer poesía y tocar instrumentos. En su obra se puede observar la relevancia que da a la expresión popular, el arte, la cultura, la lúdica y la recreación en el pueblo, así como a la alegría y unidad de gente durante los festivales como el de cometas en Jericó (Hilos de Libertad, 2003). De la historia de estos espacios y su gente, que son prácticamente la excepción, tratan los bellos relatos de Osca Mario Estrada, que nos dice que en el pueblo no solo se albergan los fantasmas de la memoria, sino la utopía de un lugar para el encuentro, en tal tesitura será un deber social y cultural su preservación. 
Bernal y Restrepo también se ocupan del campo. Para el primero como lugar más tranquilo que la ciudad, en el documental 1526 metros sobre el nivel del mar (2004) dice un campesino: "La verdad en Medellín no me veo viviendo en algún tiempo. Que me toque irme a vivir allá por razones de fuerza mayor, pero no está dentro de mis planes. ¿Por qué razón? porque la verdad cuando voy por allá a Medellín me siento como encerrado estresado, por la contaminación, por el ruido, el agite de todo el mundo que se vive en la ciudad. En cambio uno acá vive tranquilo, se acuesta y nadie lo molesta. No hay un bus que esté pitando, no hay la gente que esté gritando".

En la ruralidad que registra Restrepo así como en la ciudad y el barrio, se está vitalmente cohesionado al drama, la tragedia y la comedia. Los campesinos, no tienen donde vender sus productos, pero tienen teléfono celular (Aristas de la Escalera; 2011). Ese espacio vital del campesino está siendo penetrado por la modernidad y los nuevos proyectos al servicio del turismo (Arví Engaño, 2011). Los campesinos siguen apegados al Sagrado Corazón de Jesús, mientras en las veredas todavía se sacrifica al "marrano" para festejar la fiesta de navidad, aunque el discurso civilizatorio se refiera al no maltrato animal (La Marranada (2006). En este espacio hay más risas, picardías, sonidos de la naturaleza que podrían ser signos de que en ese lugar hay más esperanza a pesar de todo.

La ciudad es advertida por Bernal como un lugar con alto nivel de contaminación ambiental, situación que registraba desde 1991, en Acordeón de papel, cuando abordó el tema del reciclaje, y que en "1526 metros sobre el nivel del mar" (2004), refiere más directamente. A esta fecha 2019, la contaminación ambiental en Medellín es uno de sus problemáticas más graves. En la ciudad documentada por Bernal, solo hay transeúntes nunca más vuelto a ver. La ciudad y el campo de Bernal siguen su tránsito hacia realidades más caóticas, pero no por ello dejan de ser bellos y entrañables. En esos sitios la violencia irrumpe así como el concreto, el hierro, la radio y la televisión. La ciudad habitada, percibida, narrada, documentada por Restrepo, es la que está en la ladera, en el declive de la montaña, a donde ahora llega el metrocable; también es una ciudad nocturna, habitada y transitada por sujetos en trance, por extranjeros deseosos de vivir y entender esta urbe en la que hay paramilitarismo, mafias; falta educación, los medios de comunicación "vende" basura y Pablo Escobar sigue siendo héroe (Caw pax, 2004)

En la periferia de la ciudad, registrada por Restrepo, hay barrios, urbanos- rurales, allí hay "piscos", niños y droga. En estos la gente transita entre la pobreza, el conflicto, la guerra. Los niños juegan en la calle esquivando los buses que reclaman su espacio. Barrios en los que las historias de marginalidad, desencanto y también de superación son pan de cada día. Barrios en los que los cristianos, tienen sus más fieles discípulos y la vida parece un mal trance (Irrevherencia, 2012).

El registro de imágenes, opiniones y sensaciones de Joche sin duda son potentes para reflexión del sentido de humanidad. Es evidente su interés por los campesinos y los marginados. Sin embargo su obra no ha tenido eco y mayor repercusión, tampoco es considerada como de denuncia. Se podría pensar en registros audiovisuales, tipo editoriales quizás videoarte, en los que él plasma sus ideas de manera metafórica apoyado en imágenes que no necesariamente se suscriben al lugar que alude. Esta ciudad, este barrio, ese campo, son contexto, fondo, acaso ¿no lugares, perpetuados en lugares por el video? ¡ ¿acaso nos está diciendo que los "no lugares" tal y como los entendió Marc Augé, no existen? y ¿los lugares tampoco? Solo hay circunstancias de drama, tragedia y marginalidad de humanos y animales por alguna razón sobreviviendo en este mundo. 
En la diferencia en cuanto a perspectivas narrativas y abordajes, la región antioqueña, su cultura e idiosincrasia está presente en la obra documental estudiada, no en un real sentido crítico del "ser y hacer", en tanto no hay un responsable, ni críticas a una cultura antioqueña, en la que la posesión de la tierra por parte de los grandes terratenientes ha sido una de las causas de la marginalidad, una región en la que los grandes industriales se enriquecieron a costa de obreros textiles y cementeros que no lograron salir de la pobreza; una industria que contaminó y contamina aún hoy día.

Una región en la que los jóvenes prefirieron la delincuencia y el narcotráfico a 30 años en la fábrica. Una región en la que mientras se venera a la Virgen se ultraja a la mujer, se violan niños, se registran feminicidios y un alto nivel de violencia intrafamiliar. Una antioqueñidad atada al Sacrado Corazón de Jesús, el ave María y el pecado en el que se esconde la doble moral, la corrupción, el narcotráfico y los caciques políticos. Una cultura de la moda (Valle, 2015) la estética y el dinero fácil. Un lugar moderno de esperanza e innovación en la que el desempleo, la delincuencia y la mendicidad abundan. El cineasta Víctor Gaviria [34], oriundo de Antioquia, se ha encargado de reflejar la realidad social de esta región con obras como Rodrigo D, No futuro (1990), La vendedora de rosas (1996-1998), Sumas y restas (2001-2004), La mujer del animal (2017) entre otras.

Es importante continuar con estos análisis para tratar de encontrar las perspectivas o miradas de una región altamente compleja como la es la antioqueña. La riqueza y calidad del conocimiento que se logró en este estudio, esperamos sea referente para los futuros comunicadores audiovisuales, investigadores y profesores. De este estudio se presentaran otros artículos y libros, en los que se abordará el tratamiento estético que estos documentalistas han desarrollado en sus obras, así como los personajes y demás temáticas manifiestas en su producción audiovisual.

\section{Bibliografía}

Aumont, J.; Bercala, A.; Vernet, M. (1983). Estética del cine: espacio fílmico, montaje narración, lenguaje. Editorial Piados Comunicación, Barcelona.

Argullol, R (1983). La atracción del abismo. Barcelona: Editorial Bruguera.

Balandier, G. (1992). El poder en escenas. De la representación del poder al poder de la representación. Paidós, Barcelona.

Barthes, R. (1973). El placer del texto. Siglo XXI editores, Madrid.

Bordwell, D.(1985). La narración en el cine de ficción. Editorial Paidós, Barcelona. Bourdieu, P. (1997). Sobre la Televisión. Anagrama. Barcelona.

Calabresse, O. (1989). La era neobarroca. Ed. Cátedra, Madrid.

Cassany, D. (2000). Describir el escribir.

Casseti y Di Chio (1991). ¿Cómo analizar un film? Paidós, Ibérica S.A.

Chion, M. (1999).El Sonido. Paidós. Barcelona.
D’abbraccio Krentzer, G. (2016). La Industria del cine en Colombia. Entre el optimismo ingenuo y el pesimismo crónico. Revista Luciérnaga Comunicación, 7(14), 36-45. Doi: https://doi.org/10.33571/revistalucierna ga.v7n14a1

Debray, Régis. (1992). Vida y muerte de la imagen. Historia de la mirada en occidente. Paidós, Barcelona.

Eisenstein, S. M.(2001). Hacia una Teoría del Montaje. Paidós. Barcelona.

Estrada Vásquez, O. (2015). El Cine Colombiano y su correlato en la historia. Revista Luciérnaga Comunicación, 7(14), 22-35. Recuperado de:

https://revistas.elpoli.edu.co/index.php/ luc/article/view/816

Estrada Vásquez, O. (2015). El audiovisual patrimonio cultural: catálogo de la obra audiovisual de Oscar Mario Estrada. Revista Luciérnaga Comunicación, 4(7), 65-71. Recuperado de:

https://revistas.elpoli.edu.co/index.php/ luc/article/view/249 
García Ángel, A. (2015). Televisión en Colombia: surgimiento de los canales regionales. Revista Luciérnaga

Comunicación, 4(7), 23-35. doi:

https://doi.org/10.33571/revistaluciernaga. v4n7a3

Disponible en:

https://revistas.elpoli.edu.co/index.php/luc /article/view/283/250

Gauthier, Guy. (1992). Veinte Lecciones sobre la Imagen y el Sentido. Cátedra.

Gómez Sánchez, Santiago (2018). Régimen de criterios. Cines y Cineastas colombianos. deliberar. Casa Editora. Medellín.

Gómez, Sánchez. Santiago (2013). Madera Salvaje. Obtenido de El cine de José Miguel Restrepo Moreno. Tomado de :

http://realidadescontadasaudiovisuales.blo gspot.com/2016/04/el-cine-de-jose-miguel -restrepo-moreno.html

Gómez, Santiago Andrés (2017). Un intercuadro, un cuadro entrometido, en El eco de la voz del viento (Estrada, 2011). Recuperado de:

http://maderasalvaje2017.blogspot.com/2 017/06/el-audiovisual-en-antioquia-c-2009. html

Gómez, Santiago Andrés (2017). El audiovisual en Antioquia. (c. 2009). Recuperado de:

http://maderasalvaje2017.blogspot.com/2 017/06/el-audiovisual-en-antioquia-c-2009. html

Groupe, U. (1992). Tratado del Signo Visual. Cátedra. Madrid.

Gruzinski, S. (1995). La guerra de las imágenes. De Cristóbal Colón a BladeRunner, Fondo de Cultura Económica, México.

Leroi-gourham, Andrei (1971). El gesto y la palabra, Ediciones Biblioteca de la Universidad Central de Venezuela, Caracas. Mckee, R.(2002). El guion. Sustancia, estructura, estilo y principios de la escritura de guiones. Alba Editorial, Barcelona.

López Cerquera, N. (2018). Cine Con Mirada Local. Práctica política que recupera y resiste. Luciérnaga, 9(18). doi: https://bit.ly/3aHyOzT
Pérez - Tornero, J. (2000). Comunicación y Educación en la Sociedad de la información. Paidós.

Restrepo - Moreno, J. (2015). La pornomiseria del actor de cine y tv: a propósito de la muerte de "aranguito". Revista Luciérnaga Comunicación, 2(4), 49-60. Recuperado de:

https://revistas.elpoli.edu.co/index.php/luc /article/view/262

Rojas Hernández, E. (2015). Cine De Arte Y Ensayo En Colombia: Los viajes del viento (2009), El vuelco del cangrejo (2010), La sirga (2012), Porfirio (2012) y La Playa D.C. (2012). LUCIÉRNAGA, 7(14), 1-21. Recuperado de https://revistas.elpoli.edu.co/index.php/luc/ar ticle/view/815

Tarkivski, A.(1993). Esculpir en el tiempo. Centro Universitario de Estudios Cinematográficos. Universidad Nacional Autónoma de México, México.

Valle Flórez, M. (2015). Research in Communication in Antioquia Colombia. Luciérnaga/communication journal, year 6, N12. Pages. 54-72. Disponible en: https://revistas.elpoli.edu.co/index.php/luc /article/view/530/565

Valle, F. Mónica; Ruiz \& Otras. (2015). Etnografía de la Teleaudiencia de Medellín. Hábitos, uso y contextos de consumo. Revista Luciérnaga Comunicación, Año 6, N11. Págs. 1-14. doi:

https://doi.org/10.33571/revistaluciernaga.v6 n11a1

Disponible en:

https://revistas.elpoli.edu.co/index.php/luc/ar ticle/view/361/419

Valle Florez, Mónica María (2015). Metáfora de la moda y de la percepción en la construcción social y cultural del clúster textil/ confección, diseño y moda de Antioquia. Revista Politécnica. [S.I.], v. 6, n. 11, p. 38 - 45. Disponible en:

https://bit.ly/2E9ozIP

Verón, E.(2001). El Cuerpo de las Imágenes. Norma. Bogotá.

Vogler, Christopher. (2003). El viaje del escritor. Intermedio, Bogotá.

\section{Notas}

[1] Conocido en su época, a principios de siglo XX, como "el fabricante de sueños", Gonzalo Mejía (1884 - 1956) fue un empresario visionario, fundador de la primera aerolínea de América (Farman 40) y promotor de proyectos tan faraónicos como la carretera a Turbo, que aún hoy no se termina. A mediados de los años veinte se le ocurrió liderar una superproducción de cine colombiano, al estilo de los típicos dramas hollywoodenses de aquellos tiempos: Bajo el cielo antioqueño (1925), cuya dirección dejó en manos del reconocido cineasta bogotano Arturo Acevedo, pero que, con su inventario visual de los paisajes, las fiestas y las industrias antioqueñas, refleja punto por punto el 
típico orgullo paisa por la propia tierra y por la tradición, del que Mejía era, por supuesto, uno de los representantes por excelencia. Gómez, Santiago Andrés (2017). El audiovisual en Antioquia. (c. 2009). Recuperado de:

http://maderasalvaje2017.blogspot.com/ 2017/06/el-audiovisual-en-antioquia-c-2 009.html

[2] Camilo Correa (1913 - 1990) se destacó primero como crítico de cine, lo que fue en esencia, en medios impresos como el diario El Colombiano y la revista Micro, desde donde fustigaba los vicios recurrentes de un cine colombiano que hacía de las producciones mexicanas su modelo principal. En 1946, Correa fundó Procinal, compañía con la que produciría cine, primero en Bogotá (en especial el Noticiero Colombia), y luego en Medellín. En los cincuenta, con el concurso de la gente del pueblo, a la que Correa congregó en una manifestación pública "en pro del cine nacional", Procinal se convirtió en Sociedad Anónima y produjo Colombia Linda (1955), cuyo estruendoso fracaso llevó al cierre de la empresa, al remate de todos sus bienes $y$ al encarcelamiento de Correa, en un hecho que inspiró luego a Luis Alberto Álvarez y a Víctor Gaviria para escribir a cuatro manos su famoso texto Las latas en el fondo del río (Revista Cine, No 8, mayo/junio, 1982). Santiago Andrés (2017). El audiovisual en Antioquia. (c. 2009). Recuperado de:

http://maderasalvaje2017.blogspot.com/ 2017/06/el-audiovisual-en-antioquia-c-2 009.html

[3] Después de trabajar en Procinal al lado de Camilo Correa, Enoc Roldán (1915-1988) se forjó su propia carrera como cineasta filmando matrimonios, partidos de fútbol y corridas de toros, pero durante los años sesenta realizó tres importantes largometrajes de ficción : Luz en la selva (1960), sobre la Madre Laura, famosa misionera antioqueña; El hijo de la choza (1961), sobre la vida del escritor y político Marco Fidel Suárez, que de un origen en extremo humilde pasó a ser presidente de la república, y El Ilanto de un pueblo (1965), un drama pasional con el trasfondo del desalojo de los habitantes del pueblo El Peñol para la construcción de una represa. Más destacable aún que esas películas es el modo en que Roldán las exhibió: de su propio bolsillo, viajando de pueblo en pueblo, y llegando así, en algunos casos, a recuperar su inversión... Santiago Andrés (2017). El audiovisual en Antioquia. (c. 2009). Recuperado de: http://maderasalvaje2017.blogspot.com/ 2017/06/el-audiovisual-en-antioquia-c-2 009.html

[4] Juan Escobar y Regina Pérez nacieron en Medellín en la década de los cincuenta y se conocieron estudiando Artes en la Universidad Nacional de Medellín. Antes de hacer cine juntos, cada uno había hecho una película en Super 8. Regina había dirigido Para Any (1981), una película centrada en su hija, y Juan había hecho Cristóbal, el carnicero (1981). La primera obra que firmaron en conjunto fue un documental sobre el grupo de teatro La Fanfarria, uno de cuyos miembros es hermano de Regina ( $Y$ dónde está la sal, dónde está la harina, 1982). Después de este trabajo, harían cinco películas más, entre las que se destacan Será por el silencio (1983), que aunque fue filmada en super 8 , les valió el reconocimiento público del influyente crítico Luis Alberto Álvarez, Melina (1984), película de ficción, filmada en los Estudios Ivo Romani, de Medellín, y los contemplativos documentales etnográficos Lunes de feria (1986) y Guayaco (1990). Las tres últimas tendían a dejar el ámbito familiar que había caracterizado sus primeras películas, pero los numerosos problemas que Escobar y Pérez debieron afrontar para terminar Guayaco los llevaron a abandonar el cine. Santiago Andrés (2017). El audiovisual en Antioquia. (c. 2009). Recuperado de: http://maderasalvaje2017.blogspot.com/ 2017/06/el-audiovisual-en-antioquia-c-2 009.html

[5] Gonzalo Mejía, nacido, como Gaviria, Juan y Regina, en los años cincuenta, se inició en el cine al lado del camarógrafo Rodrigo Tamayo, con el documental Hulleras (1980), sobre una tragedia minera en Amagá. Junto con Víctor Gaviria, que también apenas comenzaba por entonces en su carrera como cineasta, a principios de los ochenta Mejía intentó hacer un famoso proyecto que quedaría inconcluso, titulado La jirafa y el parque, y luego dirigieron juntos La vieja guardia (1985). La baja (1987), una historia de violencia soterrada en una guarnición militar, realizada como parte de los mediometrajes que produjo FOCINE para la televisión, es considerada como la mejor de sus películas. Muy consciente de sus propias características como cineasta, 
y divergente de Gaviria por sus mayores escrúpulos en la producción, el menos osado Mejía después no ha producido mucho, y tampoco acepta ser un asalariado de la televisión. Después del documental Retrato hablado (1991), y de los mediometrajes de ficción Canturrón (1990) y El evangelista (1992), ha intentado producir diversos proyectos de largometraje, de los cuales apenas ha cuajado El gran Sandini. Santiago Andrés (2017). El audiovisual en Antioquia. (c. 2009). Recuperado de:

http://maderasalvaje2017.blogspot.com/ 2017/06/el-audiovisual-en-antioquia-c-2 009.html

[6] Carlos Mario Bernal Acevedo. Nació en La Ceja, Antioquia, Colombia (1960). Actualmente es profesor de tiempo completo del Programa de Cine y Audiovisuales de la Universidad del Magdalena. En su amplia obra encontramos películas como Son del barro (1986), África tierra madre (1989) emitido por DW y 3 Sat en Alemania, Fue anunciada (1989), Los niños en la vía (1990) emitido por televisión española, Acordeón de papel (1991), El Mundo es plano (1999), 1526 Metros sobre el nivel del mar (2004), entre otras. Bernal ha analizado el documental no solo desde un punto de vista práctico, sino también académico, como pueden demostrarlo sus publicaciones y numerosas cátedras y talleres dictados sobre el tema. Ha tenido una participación en diferentes proyectos televisivos como: la producción del seriado documental sobre migración internacional, realizado en Chile, Vietnam, Eritrea y Alemania, Ich kehre mit zäher Liebe zurück (Regreso con mi amor espeso, 1993-1994) para el BMZ (Bundesministeriums für wirtschaftliche Zusammenarbeit und Entwicklung) de Alemania; director de fotografía de Caracol (1995); director de Portadores de música (2000) para el Ministerio de Cultura y la Organización de Estados Iberoamericanos. "Para conocer más sobre el trabajo de Bernal, el mejor abrebocas es la entrevista que le hizo Luis Alberto Álvarez en Kinetoscopio 9 (septiembre/octubre, 1991), donde se encuentra prácticamente todo el ideario del documentalista". Gómez, Santiago Andrés (2017). El audiovisual en Antioquia. (c. 2009). Tomado de http://maderasalvaje2017.blogspot.com/ 2017/06/el-audiovisual-en-antioquia-c-2 009.html

[7] Oscar Mario Estrada Vázquez. Comunicador social y periodista de la Universidad de Antioquia, Especialista en Televisión Educativa de la Fundación Konrad Adenauer. Master en
Comunicación y Educación de la Universidad Autónoma de Barcelona. Formado en Guion Cinematográfico en la Escuela Las Aulas de Madrid y en Producción Cinematográfica con el Ministerio de Cultura de Colombia. Docente en los talleres de Formación Audiovisual de la Alcaldía de Medellín en las comunidades de Aranjuez, El Poblado y corregimiento de Palmitas. Docente de las áreas de realización documental y argumental, apreciación de cine, cine 1 y cine 2, guion, cine documental y cine en la Historia; en las Universidades Autónoma de Bucaramanga, Cooperativa de Colombia, Politécnico Colombiano Jaime Isaza Cadavid, y Universidad de Antioquia. Co-investigador de "Realismos en el cine" proyecto ejecutado por la Universidad de Antioquia. Ex-Director Programa la vida, la fórmula y spot publicitarios de Comfama Televisión y de Producción Noticias UNA. Ex-Coordinador del Centro de Televisión de la Universidad de Antioquia. Algunos trabajos audiovisuales en los que ha participado, producción escrita, nominaciones y premios recibidos: Realizador Serie "Muchachos a lo bien". 1995-1996; Seriado de televisión "Del Arbol, la semilla", Los Vieco Ortiz, memoria, patrimonio y ciudad; Editor telerevista Universidad de Antioquia. 1990-1992; Editor documental. "200 años un día", directora Elena Correa; Editor documental. Indigentes Medellín, Director Ricardo Aricapa; Editor documental. Proyecto urbanístico, quebrada la Yesca en Quibdó (chocó). Director; Editor cortometraje argumental taller de "la Idea a la realización", con el Maestro Dunav kusmanich; Director mediometraje argumental "Partida final", Facultad de Comunicaciones Universidad de Antioquia, 1991; Realizador documental sobre corregimiento de Versalles (Antioquia), con la Fundación Laubach; Realizador Video Institucional Colanta. Versión Español-Inglés.2001; Realizador video "Objetivo democracia". Versión Español-Inglés.2002; Realizador documental "Por qué alumbran las luciérnagas". Fundación Fasor. El Retiro (Antioquia) 2003; Realizador Video institucional Cotrafa. 2003; Realizador video "Los olvidados". Universidad Autónoma de Bucaramanga. 2004. CoRealizador miniserie documental de seis capítulos. "Del árbol, la semilla. Realizador documental: "México en el espejo del Cine". 2006; Realizador capitulo documental acerca de la vivienda en Seriado sobre la Comuna Uno de Medellín. 2006. Realizador campaña audiovisual promocional Museo Cementerio San Pedro, integrada por tres promos y un trhiller. 
Medellín. 2006; Realizador video documental "los colores de Altavista", para la corporación Cedecis. Medellín. 2006. Realizador Video promoción y prevención en salud, referencia: "la cadena de la vida", para COMFAMA. Medellín. 2006. Realizar video Derechos Humanos Comuna 6 de Medellín, para la Corporación Simón Bolívar 2007. Realizador video "El Ingenio de Don Efe Gómez", para la serie de televisión de Teleantioquia: "Antioquia, Letra a Letra" 2007. Realizador Cortometraje "El cruce", para Municipio de Medellín 2007. Realizador video "Las cuentas claras" para los municipios de Caldas y Fredonia (Antioquia). Realizador video "Thana", sobre el escritor Gregorio Henríquez, para Funeraria San Gabriel 2008. Realizador video Balance Comfama, para las asambleas 2007-2008. Realizador vídeo Biblioteca de Caldas Nueva sede. Realizador vídeo "Cuerpo Concentrico", Instituto de Educación Física y deportes de la Universidad de Antioquia. 2008. Realizador vídeo "Vive Necoclí, 500 años de Historia" 2008. Realizador Vídeo "La película de Pacholo" 2008. Co-realizador video "Don Tomás en Medellín", en torno a la obra y vivencias del escritor Tomás Carrasquilla en Medellín. 2008. Realizador video: "15 años Grupo de Cultura Somática UdeA" 2009. Para verte mejor, Comfenalco Antioquia, 2009. Olvido general: Rafael Uribe Uribe en la memoria, 2009. Con tus ojos y el cine en Cartagena, 2010. Comfama, video corporativo asamblea, 2010. Bibliocirco, Comfenalco Antioquia, 2010. Ciudad en letras, documental, 2010. Realizador documental y miniserie de El Bicentenario: reflexiones, imágenes y representaciones sobre la Independencia de Colombia y Antioquia, 2010-2011 con Universidad de Antioquia y Alcaldía de Medellín. Quien no se olvida, documental, 2011.

[8] José Miguel Restrepo Moreno. A mediados de octubre de 2017 contabiliza cerca de 700 documentales de variados formatos y tiempos, lo que da cuenta de su constante producción-realización audiovisual que migra del género documental, a la ficción y de este al video arte $y / o$ al video experimental. Hibridando, siempre hibridando los lenguajes se muestra como un realizador bastante versátil que se inquieta bastante por el oficio desde cada rol: camarógrafo, sonidista, editor, productor. En compañía de algunos compañeros montó un canal en Youtube, llamado Independientes Pendientes, dedicado al género documental y "otros menesteres" audiovisuales. Aunque se declara detonador de acciones políticas a través de su oficio, el tema de su pasión, nacido por visibilizar el drama de los marginales a donde quiera que vaya, se amplía por un goce-pasión en y por medio de asuntos estéticos, incorporados en el video, y en las artes como tal. Confabulado en contra de los dogmas y las convenciones, del que él piensa "el más maleable de los géneros", lucha haciendo y construyendo permanentemente estructuras novedosas en sus narraciones para ampliar el espectro del documental en su contexto. "El documental puede y debe dar mucho más que información" comenta entre tintos negros y calientes a sus estudiantes por fuera de los espacios de clase, pues, su clase es esa, "compartir, salir y ver, salir y oír, mezclarse entre la gente, entre el aire revuelto, y las sombras proyectadas de la siempre presente luz, para desaparecer y cazar... Imágenes, sonidos, una y otra vez. Eso es este oficio por el que damos un pedazo de vida, a cambio de aprender, conocer, extrañar, pues, la vida misma siempre está y estará por encima de cualquier cosa que hagamos como actividad humana. Esto de hacer documental es entretenido y hasta necesario en la sociedad, pero no hay que ser fanáticos, mucho menos engreídos" vuelve a ampliar la reconvención ilustradora, y se prepara para ir con tres de sus compañeros (así nombra a sus alumnos) a un barrio marginal en donde hay presencia de grupos armados, repleto de como él dice "gente linda y amable". Le da vueltas en el fondo al último sorbo que hay en su vaso plástico arrugado por tantos tintos en el mismo recipiente. "Hay que llegar, preguntar, respetar, entrar o salir. No es más. Dios va por delante." Termina su café de un trago, guarda el vaso plástico en el maletín, al lado mismo de su cámara actual, se ríe mirando a todos de sus compañeros a la cara y arranca la marcha. Todos caminan alegremente, como quien va para un día de campo. Esa misma noche volvió a su oficina abajar el material. 21 GB de imágenes y sonidos en los que reposaba un documento aún no nombrado, acerca del manejo que hacen los paramilitares y los combos del agua en la parte alta del barrio Nueva Jerusalén. (Audio grabado con celular en tertulia de tintos tienda doña Gloria, PCJIC, 5 de octubre de 2017).

[9] Carlos Bernal Acevedo es profesor de planta en el Programa Cine y Audiovisual de la Universidad del Magdalena. Oscar Mario Estrada es profesor de Catedra en varias universidades. José Miguel Restrepo Moreno es profesor de tiempo completo en la Facultad de Comunicación Audiovisual del Politécnico Colombiano Jaime Isaza Cadavid. 
[10] Teleantioquia. Canal Regional https://www.teleantioquia.co/

[11,34] Víctor Manuel Gaviria González (Liborina, Antioquia, 19 de enero de 1955) es un director de cine, guionista, poeta y escritor colombiano. Psicólogo y Doctor Honoris causa en Comunicaciones de la Universidad de Antioquia, es uno de los cineastas colombianos más reconocidos internacionalmente. Sus tres largometrajes han ganado numerosos premios internacionales, e incluso dos de ellos fueron parte de la selección oficial del Festival de Cannes. En su obra, Gaviria es reconocido por reflejar la realidad social de su país. Recuperado de: https://es.wikipedia.org/wiki/V\%C3\%ADc tor_Gaviria

[12] Gómez, Santiago Andrés (2017). El audiovisual en Antioquia. (c. 2009). Recuperado de:

http://maderasalvaje2017.blogspot.com/ 2017/06/el-audiovisual-en-antioquia-c-20 09.html

[13] El material audiovisual de Estrada, fue adquirido por el sistema Municipal de Bibliotecas de la ciudad de Medellín por considerar, que dichas producciones son de gran valor histórico, patrimonial y fuente de consulta para estudiantes, profesores e investigadores de las ciencias sociales, instituciones y comunidad en general. Estrada, O. (2012). El audiovisual patrimonio cultural: catálogo de la obra audiovisual de Oscar Mario Estrada. Revista Luciérnaga Comunicación, 4(7), 65-71. Recuperado de:

https://revistas.elpoli.edu.co/index.php/lu c/article/view/249

[14] El término inglés pitch hace referencia a una presentación verbal (y visual, a veces) concisa de una idea para una película o serie de televisión, generalmente hecha por un guionista o director a un productor o ejecutivo del estudio, con la esperanza de atraer financiación de desarrollo para costear la escritura de un guion. Recuperado de: https://es.wikipedia.org/wiki/Pitch

[15] Melitón Rodríguez (1875 1942).Fotógrafo de la ciudad de Medellín - Colombia, su nombre está asociado al desarrollo de la fotografía del siglo XIX y principios del XX. Su archivo contiene valioso material cultural, social e histórico. Rodríguez retrató la cotidianidad de todos los estratos sociales de su ciudad. Recuperado de :

https://es.wikipedia.org/wiki/Melit\%C3\% B3n_Rodr\%C3\%ADguez
[17] Ex integrante de Madera Salvaje, docente en el área audiovisual en la Universidad de Antioquia.

[18] Bandas Emergentes en Colombia o Bandas Criminales (BACRIM), conocidas oficialmente por el gobierno como Grupos Armados Organizados (GAO), Grupos Delincuenciales Organizados (GDO) o Grupos Armados Organizados Residuales (GAOR), son términos con los que se han identificado unas organizaciones mafiosas que operan en Colombia y que son parte del conflicto armado interno. Recuperado de :

https://es.wikipedia.org/wiki/Bandas_eme rgentes_en_Colombia

[19] Carlos Vieco Ortiz (Medellín 14 de febrero de 1094- 13 de septiembre de 1979). Compositor, folclorísta considerado uno de los representantes de la música andina de la región de Antioquia. Su voluminosa producción aún está por estudiarse alcanzando alrededor de 1800 obras. Recuperado de :

https://es.wikipedia.org/wiki/Carlos_Viec o_Ortiz

[20] Beatriz Bermúdez ha sido documentalista por más de veinte años, primero en dupla con Carlos Bernal, con quien filmó Son del barro. Juntos hicieron trabajos que los identificarían, sobre todo al camarógrafo Bernal, como profesionales de primera línea, algunos de ellos legendarios (África, tierra madre -1990-, Niños en la vía -1991), pero luego de la separación del dúo -o en verdad desde un poco antes-, la carrera individual de Bermúdez se ha centrado en temas pedagógicos (Con la "raa" de árbol, 1987), de mujer (Tocador, 1992) y, desde Do-Wabura -Adiós río (1996), puramente ecológicos, tratados, a dúo con Germán Castaño, con el mismo compromiso humano y el mismo respeto que fueron notables en sus documentales con Bernal. Entre sus últimos trabajos se pueden mencionar Semillas de identidad (2008) y Plantaciones forestales (2008). Recuperado de :

http://maderasalvaje2017.blogspot.com/ 2017/06/el-audiovisual-en-antioquia-c-20 09.html

[21] Edificio Coltejer. Se empezó a construir en 1968 y se terminó en 1977, en su época el más alto de Latinoamérica. Este rascacielos lo mandó a construir Rodrigo Uribe Echavarría, gerente de la textilera Coltejer, popularmente se dice que el último piso de este rascacielos, simula un ojo en el que se enhebra el hilo de una aguja. Recuperado de : https://es.wikipedia.org/wiki/Centro_Colt ejer 
[22] Torre Argos o Edificio de los espejos, es un edificio de 20 pisos ubicado en la zona centro de Medellín, Antioquia, Desde el 2006, sede de la Red de Servicios Empresariales y de Emprendimiento. El edificio fue construido por la Cementera Argos, líder de esta industria en el País, América Latina y Centro América. Recuperado de: https://argos.co/Acerca-de-Argos/Histori a-de-Cementos-Argos

[23] La expresión se utiliza en Colombia para designar a una persona de corta edad.

[24] "no-lugar" lugares de transitoriedad que no tienen suficiente importancia para ser considerados como "lugares". Un no-lugar es una autopista, una habitación de hotel, un aeropuerto o un supermercado... Carece de la configuración de los espacios, es en cambio circunstancial, casi exclusivamente definido por el pasar de individuos. No personaliza ni aporta a la identidad porque no es fácil interiorizar sus aspectos o componentes. Y en ellos la relación o comunicación es más artificial. Son lugares antropológicos los históricos - los vitales, así como aquellos otros espacios en los que nos relacionamos.

[25] Paramilitar o paramilitarismo se refiere a organizaciones particulares que tienen una estructura, entrenamiento, subcultura y, a menudo, una función igual a las de un ejército, pero no forman parte de manera formal a las fuerzas militares de un Estado. Son grupos de poder en enquistados, y generalmente están fuera de la ley. Dentro de sus miembros pueden estar fuerzas policiales, militares, guerrilleros, mercenarios e integrantes de escuadrones de asalto o grupos de seguridad privados y políticos. Recuperado de:

https://es.wikipedia.org/wiki/Paramilitar

[26] La ciudad colombiana de Medellín cuenta con un total de 275 barrios oficiales agrupados en 16 comunas urbanas, que no solo delimitan espacios de la ciudad sino también a sus habitantes, estableciendo distancias y límites entre ellos. Recuperado de: https://es.wikipedia.org/wiki/Anexo:Barri os_de_Medell\%C3\%ADn
[27] Mafia es un término utilizado a nivel mundial que se refiere a una clase especial de crimen organizado, extendido desde su origen en el Mezzogiorno italiano a cualquier grupo de crimen organizado, con similares características, independientemente de su origen o lugar de acción. Recuperado de : https://es.wikipedia.org/wiki/Mafia

[28] Saltar, golpear por la acción de la música generalmente se da en conciertos de rock.

[29] Gómez, Sánchez. Santiago (2013). Madera Salvaje. Obtenido de El cine de José Miguel Restrepo Moreno. Recuperado de :

http://realidadescontadasaudiovisuales.b logspot.com/2016/04/el-cine-de-jose-mi guel-restrepo-moreno.html

[30] «Gimme Shelter» en español: «Dame Refugio», es una canción de la banda británica de rock The Rolling Stones editada en 1969. Este tema habla de la guerra, el asesinato y la violación, que están "a un solo tiro de distancia", haciendo posible alusión a los horrores de la guerra de Vietnam... Gimme Shelter el documental se realizó en 1970 y fue dirigido por los Hermanos Maysles y Charlotte Zwerin que muestra gran parte del American Tour 1969 de The Rolling Stones. . Tomado de:

https://es.wikipedia.org/wiki/Gimme_Sh elter

[31] The Last Waltz (en español, El último vals)2 fue un concierto de despedida de la banda de rock The Band que tuvo lugar el Día de Acción de Gracias de 1976 en el Winterland Ballroom de San Francisco. Tomado de:

https://es.wikipedia.org/wiki/The_Last_W altz

[32] Woodstock: 3 Days of Peace \& Music (Woodstock: 3 días de paz y música), conocido coloquialmente como Woodstock, la película, es un documental estadounidense de 1970 que narra los hechos ocurridos en el Festival de Woodstock que tuvo lugar en agosto de 1969 en Bethel, Nueva York. La publicación Entertainment Weekly la considera punto de referencia de películas de conciertos, y la cataloga como una de las mejores películas de 
entretenimento mejor realizadas. La película fue dirigida por Michael Wadleigh y editada por Martin Scorsese y Thelma Schoonmaker (entre otros), esta última nominada a los Premios Óscar de la Academia como mejor montaje. Tomado de:

https://es.wikipedia.org/wiki/Woodstock _(documental)
[33] El Parque Arví es un espacio público abierto, creado para el disfrute de toda la comunidad local, nacionales y extranjeros, que mediante una oferta turística sostenible, propende por la conservación de las riquezas ambientales, culturales y arqueológicas. Tomado de: https://parquearvi.org/

Para citar este artículo:

Valle, M.; Gómez, S.; Restrepo, J; Gómez, A.; Raigosa, W. (2019). DOCUMENTALES Y DOCUMENTALISTAS ANTIOQUEÑOS. Sentido y práctica de un oficio que narra una región. Revista Luciérnaga Comunicación. Vol. 11, Núm. 21. Pp 5 - 39. DOI: https://doi.org/10.33571/revistaluciernaga.v11n21a1

OJS. http://revistas.elpoli.edu.co/index.php/luc/issue/archive Link. https://www.politecnicojic.edu.co/index.php/revista-luciernaga 